\title{
Understanding Coronanomics: \\ The economic implications of the coronavirus (COVID-19) pandemic
}

\author{
Suborna Barua* \\ Draft Manuscript ${ }^{\dagger}$
}

1 April 2020

\begin{abstract}
The globalization of COVID-19 pandemic and its economic impacts is set to run havoc across all economies in the world, throwing many into recession and possibly economic depression. As the numbers of infected and death cases rise sharply and recovery from the pandemic remains uncertain even in developed countries, evidence of shocks across economies including China, the Europe, and the US are already emerging. The aim of this paper is to provide an overall understanding of the likely macroeconomic shocks of the pandemic, covering economic activities or areas including demand, supply, supply chain, trade, investment, price level, exchange rates, and financial stability and risk, economic growth, and international cooperation. The paper first presents a general and theoretical mapping of the likely macroeconomic impacts of the pandemic on an affected economy and then reviews the emerging evidence in relation to the impact mapping to understand the nature of the impacts. The paper then illustrates the likely impacts using a standard macroeconomic AD-AS model and outlines some necessary features that needs to be considered while designing policy responses by governments and international institutions in mitigating the economic shocks. Assessments of this paper are broadly in line with the limited studies available on the economics of COVID-19.
\end{abstract}

Keywords: COVID-19, coronavirus, coronanomics, pandemic, economic impacts

JEL codes: F40, I15, E1, E6

\footnotetext{
* Suborna Barua, PhD is Assistant Professor at the Department of International Business, University of Dhaka, Bangladesh, and the Coordinator of OBOR Research Group - an Australia-based research group; the author is thankful to Al Amni Sabbir and Farjana Nasrin for their tireless assistance in this work.

t The manuscript is under development and the current version is the first draft. All errors and omissions belong to the author and will be corrected in the next version of the manuscript. The author will be very happy to receive comments, suggestions, or observations on this draft at sbarua.du@gmail.com.
} 


\section{Introduction}

The outbreak of the novel coronavirus, named as COVID-19 (also known as SARSCoV-2) by the World Health Organization (WHO), has been declared a pandemic by the WHO. The rapid 'globalization' of the COVID-19 pandemic is something that the world perhaps has never encountered before. The infection of the COVID-19 virus was first reported in December of 2019 in Wuhan - the seventh largest city of China. Among the family of coronaviruses, the other coronaviruses the world encountered before are the Middle East Respiratory Syndrome (MERS) and Severe Acute Respiratory Syndrome (SARS). Research suggest that the outbreak began from the workers and customers slaughtering animals such as pig, dog, rat, civet cat, rat, and snakes etc. at a wholesale market in Wuhan (Chen et. al., 2020). Once infected by COVID-19, it can cause fever, cough, breathing problem, and in severe cases pneumonia and severe acute respiratory syndrome, heart failure and subsequent death. The existing antiviral drugs are of no use to cure it and scientists in different countries including China, USA, UK, and Japan are currently racing against time to develop a vaccine and a drug (Sandbu, 2020). The pandemic has ignited scientists and researchers to explore the genetic nature of the new coronavirus, its infection trends and patterns, and new tests for diagnosis. According to Stoye (2020), about 54 research papers so far have been published as of 30 January, which mostly examine epidemiological, demographic, and clinical issues of the virus and its outbreak.

Although it might seem too early to talk about the economics of the COVID-19 outbreak, it remains pertinent due to the ravage it is causing through direct and indirect economic impacts across countries. The economic implications of the outbreak is broadly termed as 'Coronanomics' (Eichengreen, 2020, 12 March), while some call it as the 'Black Swan' (Petro, 2020, March 20). Apparently, the outbreak has produced a 'de-globalization' process by forcing countries to lock-down borders, preventing normal flows of goods, capital, and humans, and business and production shut downs at least temporarily. That said, countries have already begun to feel the macroeconomic hit due to the outbreak and economists are increasing looking into them. In addition to dire health consequences, the COVID-19 outbreak is producing massive and far-reaching economic cost burdens for all nations including China, the US, Japan, Germany, Britain, France, and Italy - the G7 countries. Baldwin and di Munro (eds.) (2020) rightly say, as the G7 countries share $60 \%$ of world supply and demand (GDP), 65\% of world manufacturing, and $41 \%$ of world manufacturing exports, when they sneeze, the rest of the world will catch a cold. However, since the first COVID-19 case was reported in December 2019, only few scholarly research can be found on the economics of the outbreak, while analytical briefs are increasingly being 
covered by news media outlets and research and policy think tanks. The limited number of available organized research efforts portray an early indication and estimates of the likely impacts, mostly addressing isolated economic dimensions; for example, Baldwin and di Mauro (eds.) (2020) present a brief eBook containing initial assessments of 14 different authors about different dimensions of impacts covering general macro economy and policy, trade, supply chain, finance, banking, travel, and regional sensitivities. The outputs however are partial, due to the fact that the direction and the span of the outbreak's impacts in the coming days are uncertain. The uncertainty also makes it difficult to produce any useful quantitative estimates of the outbreak's future impacts.

This paper attempts to identify the current and future likely economic implications of the COVID-19 outbreak in a comprehensive manner. The purpose of this paper is not to produce any quantitative estimate of the future impacts (as perhaps it would take some more time make useful predictions), rather it aims to deliver a comprehensive and indicative overview on the observed and the possible impacts that could emerge in the coming days. In doing so, the paper first offers a general time-dependent (short-run and long-run) mapping of the likely macroeconomic impacts - such as on production, supply chain, trade, investments, prices, finances, exchange rates, growth, and cross-border cooperation - of the COVID-19 outbreak and then systematically reviews the impacts observed so far in the context of the mapping, i.e., the observed impacts is studied relating to the mapping presented in the paper. To explore the observed impacts, a systematic review is carried out on materials published so far by different media outlets, think tanks, research agencies, and policy experts. Furthermore, the paper offers an analysis of the likely growth and recessionary outcomes using a standard macroeconomic model and briefly outlines some key features that needs to be considered while setting policy measures in mitigating the impacts. All considered, the analyses of the paper build on available research, analysis, data, and standard macroeconomic theories related to the COVID-19 pandemic. The paper offers some key contributions in comparison to the research available so far in the current context: first, the analyses cover a wide range of economic activities and areas to provide an understanding of the broad-based macroeconomic impacts in a comprehensive manner; second, the paper's analysis builds on a unique impact mapping that helps to understand the short and long term impacts in an interlinked manner; third, the paper shows how a standard macroeconomic model can be used to reflect the pandemic's likely macro effects in a simplified way; and finally, the paper points out some key attributes that policy-makers need to consider while responding to mitigate the pandemic's economic threats. 
The paper is structured in eight sections: section 2 and 3 provide a brief overview of the COVID-19 outbreak and the relevant literature relating to its economic implications, respectively; section 4 presents the general impact mapping, followed by an examining of the observed impacts so far in section 5; section 6 presents the analysis of the likely impact using a standard macroeconomic model; section 7.0 highlights the necessary features of future policy measures, followed by a conclusion in the final section.

\section{The Outbreak of COVID-19}

The COVID-19 pandemic has become truly globalized, unfortunately. The numbers of infected cases and death globally are increasing so rapidly that the epicenter of the pandemic is moving fast. Figures 1.1(a) shows the total number of confirmed cases and deaths at the world level. As of 30 March 2020, the number of infected cases globally stand at 715660, with 33579 death cases. The number is stunningly high when compared to other similar outbreak in the past; for example, the SARS outbreak killed 774 and infected 8,098 between November 2002 and July 2003 (Woodward, 2020, February 21). However, COVID19's worldwide fatality rate as of 30 March 2020 stands at 4.69\%, while 172,435 have so far recovered. While the virus has already arrived across 200 countries and territories, the US, China, and the Europe appear to be the biggest victims. Figure 1.1(b) reports the top 15 countries in terms of number of infected cases. Initially China was the epicenter with a very high number of infected and death cases, but that moved very fast to the Europe making Italy the next epicenter. At the latest, the US tops the list with 164620 confirmed cases and 3170 deaths as of 30 March 2020, making the country the latest epicenter of the diseases.

\section{Figure 1(a): World's total number of infection and death caused by COVID-19 coronavirus}

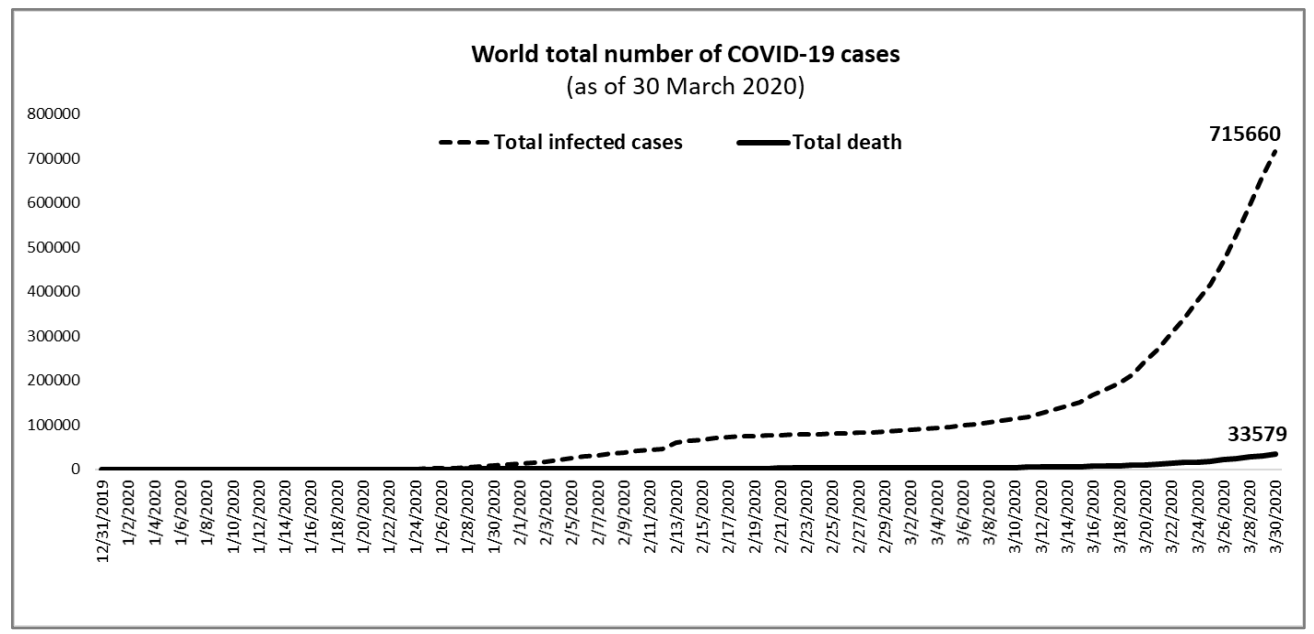

Source: author, based on data from European Centre for Disease Prevention and Control as of 30 March, 2020 
Figure 1(b): Country-wise total number of infection and death caused by COVID-19

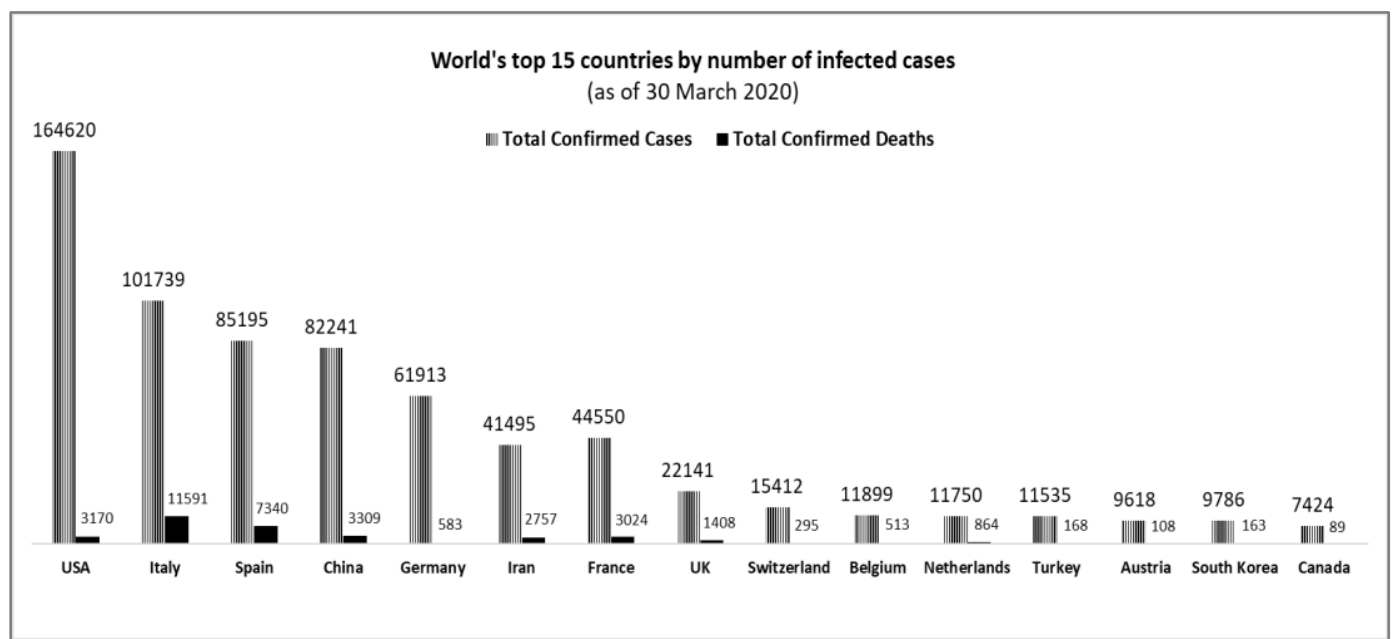

Source: author, based on data from European Centre for Disease Prevention and Control as of 30 March, 2020

\section{The economics of COVID-19: What we know so far}

Given the life of the pandemic is just about four months, research on the economics of COVID-19 is at early stage and still emerging. As the evidence of economic impacts keep emerging, research think tanks and media outlets are in a race to publish commentaries, editorials, and analytical pieces. Among the first organized efforts, Baldwin and di Mauro (eds.) (2020) compile an eBook containing 14 briefs of different authors discussing the impacts pertaining to general macro economy and policy, trade, supply chain, finance, banking, travel, and regional sensitivities. While few of the works rely on simulation-based modelling, most are based on past experience, real-time data, and intuitive and policy perspectives. Given the aim of this paper, it is worth reviewing them.

According to Baldwin and di Munro (eds.) (2020), the pandemic has affected all major economies including the G7 countries, who jointly share $60 \%$ of world supply and demand (GDP), $65 \%$ of world manufacturing, and $41 \%$ of world manufacturing exports; therefore, as these economies are now severely affected, the rest of the world will follow suit. di Mauro (2020) term such outcomes as 'macroeconomic flu' - a temporary negative supply and demand shock - causing output to fall temporarily, followed by a quick recovery and possibly a full catch-up on the shortfall. But that happens when it is a normal flu or a macroeconomic sneeze - not a pandemic like COVID-19 which is seemingly producing large scale, global, and possibly persistent economic disruption (di Mauro, 2020).

Although it might be a little early to produce quantitative estimates, Boone, Haugh, Pain, and Salins (2020) at the Organization for Economic Cooperation and Development (OECD) generated a simulated base-case (contained) scenario and a downside (broader 
contagion to Asia Pacific, North America, Europe, and other advanced countries) scenario using a NiGEM global macroeconomic model; while the base-case shows global economic growth to fall sharply in the first half of 2020 and then recovering modestly, the downside case suggests a larger decline in confidence, and a much more marked and prolonged growth slowdown. McKibbin and Fernando (2020a:2020b) utilizes Dynamic Stochastic General Equilibrium and Computable General Equilibrium modelling to produce seven pandemic scenarios and show that under all scenarios GDP growth reduces across economies globally and that if COVID-19 develops into a global pandemic, the cost in terms of lost economic output begins to escalate into the trillions of dollars. Arezki and Nguyen (2020) discusses about the four three channels of the pandemic's likely effects on North Africa and the Middle East; for example, disruptions in oil price, value chain, and tourism and travels. It is inevitable that border closures driven by the pandemic will hit hard many economies. Meninno and Wolff (2020) looked at the EU border and suggest that stopping cross-border travel would lead to a major disruption of economic activity in the EU.

Baldwin and Tomiura (2020) suggest that the COVID-19 pandemic is both a demand shock and a supply shock - that are likely to slow down aggregate trade flows significantly and that a manufacturing distress and supply-side contagion is imminent through international supply chain distortions. Beck (2020) focuses on finance and banking risks created by the pandemic and argues that the effect would depend on three factors - the extent of the pandemic's economic effects globally, the fiscal and monetary policy reactions to the shocks, and regulatory reactions addressing possible bank fragility. Among financial institutions, Cecchetti and Schoenholtzon (2020) argue that banks are highly vulnerable to the likely economic shocks and they compare the challenge with that of stemming a bank run. According to Mann (2020), the interlinkage between global commodity markets, financial markets, public sentiment, and the economy is likely to make situation worse and challenging for policy responses. To fight back with the right policy, Cochrane (2020) urge for a detailed, pandemic-induced financial crisis plan with targeted bailout packages that considers the likely bankruptcies and insolvencies and floods the country with money in the right spots. Based on the experiences of modelling the economic effects of influenza pandemic, Wren-Lewis (2020) suggest that the COVID-19 estimate reduction in economic growth, coming as a result of reduced labor supply, higher production cost, higher temporary inflation, and reduced social consumption.

In addition to the compilation of Baldwin and di Mauro (eds.) (2020), Fornaro and Wolf (2020) uses a macroeconomic model and show that the spread of the COVID-19 outbreak might cause a demand-driven slump, give rise to a supply-demand doom loop, and 
open the door to stagnation traps induced by pessimistic animal spirits. Assuming that the supply disruption will be severe and persistent, Fornaro and Wolf (2020) theoretically illustrate the pandemic might induce a demand-driven recession through its negative impact on agents' expectations of future productivity growth. Fernandes (2020) estimates GDP growth could decline by $3-5 \%$ in a mild scenario depending on the country, with a cost of about $2-2.5 \%$ of global GDP growth for each additional month of shutdown. While serviceoriented economies will take the larger hits, countries such as like Greece, Portugal, and Spain (that are largely reliant on tourism) will be more affected by this crisis. Fernandes (2020) argue that the economic effects of outbreak are currently being underestimated, due to over-reliance on historical comparisons with SARS, or the 2008/2009 financial crisis.

Further to organized research, an increasing amount of discussion is taking place in different media outlets in the forms of opinions, reviews, perspectives, and blogs contributed by experts and research think tanks. Many of them are discussed throughout the rest of the paper. Whatever discussions are available so far suggest that the pandemic is going to generate long-run and possibly persistent havoc across economies, which could trigger global economic depression. This paper contributes to the existing efforts to explore and identify the likely broad-based, short-run and long-run macroeconomic impacts by combining theories and available evidence.

\section{A possible mapping of the macroeconomic implications of the COVID-19 pandemic}

The COVID-19 outbreak has already began to affect how economic agents behave across economies, i.e., beginning from the lifestyle and socialization to economic activities of people and firms. The outbreak's toll will stretch out across both micro and macro levels. For example, productions in China and some other countries have already been temporarily suspended by many large multinational companies, and transport routes through air and sea to and from China and many other economies have already been closed down, resulting in a partial or full border 'locked down' (Wilson, 2020, Whalen \& Bhattarai, 2020, Cohen \& Kupferschmidt, 2020). Although the ultimate outcome of continued adverse economic impacts could be a long-lasting recession, the effect mechanism, i.e., how a pandemic affects economic activities and agents, is likely to be more or less different compared to other known events resulting in a similar outcome, e.g., the 2008-09 global financial crisis. One peculiarity of the current case is that the end to the pandemic remains uncertain, and thus the direst consequences are likely to arise in the long-run if it is not stopped soon.

Figure 2 shows a general theoretical mapping of the likely economic impacts of the COVID-19 pandemic; showing what 'could be' the impact's span and progress line. It is 
useful to consider the mapping in the macroeconomic context of one single country. The figure assumes different waves of impacts over time, where many of the impacts could be visible in the short run while others in the long run. Furthermore, many of the impacts could be happening concurrently while others sequentially. To begin with the first wave, the immediate and direct impact of the COVID-19 outbreak is temporary shutdown of factories and businesses in an affected country (as it is the case in China by now) and thereby, resulting in a sharp and immediate decline of production in the economy. The shock then could be amplified by a simultaneous supply chain disruptions of necessary production inputs and immediate drop in demand; demand for goods and services declines as consumers follow 'saving for emergency', 'wait and see', and 'hoarding' during the crisis (Baldwin \& Tomiura, 2020). Also, as pandemic spreads across the world, foreign demand for an economy's goods may slump substantially, which in turn will depress production (this might create a situation termed as supply-demand doom loop by Fornaro \& Wolf (2020)).

However, there is an important aspect of the demand response. In a pandemic driven panic environment, demand shocks could be different for (i) essential goods and (ii) nonessential (including luxury) goods. Essential goods are those that are necessary for living, for example, food, medicine, and shelter; while non-essential goods such as cars, tourism are not a necessity for living. In a pandemic situation, demand for essential goods such as food and medicine goes sharply up, while that for non-essential good sharply declines, since people tend to save money for their health emergencies, shopping and outdoor entertainment are restricted, and panic drives people to not spend unless it is really urgent.

To worsen the situation, lower production and supply, driven by demand drops, manufacturing hits, and supply chain disruptions, sends back some effects to the global supply chain, particularly when the rest of the world significantly relies on the affected economy (such as China) for production inputs. In addition, when domestic and international transports and logistics channels are suspended by the country in an effort to stop the pandemic's spread, it could further disrupt the supply chain. And if the affected economy is a world's major manufacturing-supply hub like China, a continued disruption could eventually breakdown or collapse the global supply chain. Furthermore, both production and supply chain would be substantially interrupted due to no to fewer human movement both domestically and internationally as restrictions and border closures are imposed. Globally, restrictions of people movement and lock-down are so far considered the most effective ways in preventing the transmission of COVID-19. It is worth noting that all these effects in the first wave could be interrelated to some extent and occur concurrently in the affected economy. 
Figure 2: A general mapping of the likely economic impacts of COVID-19 outbreak

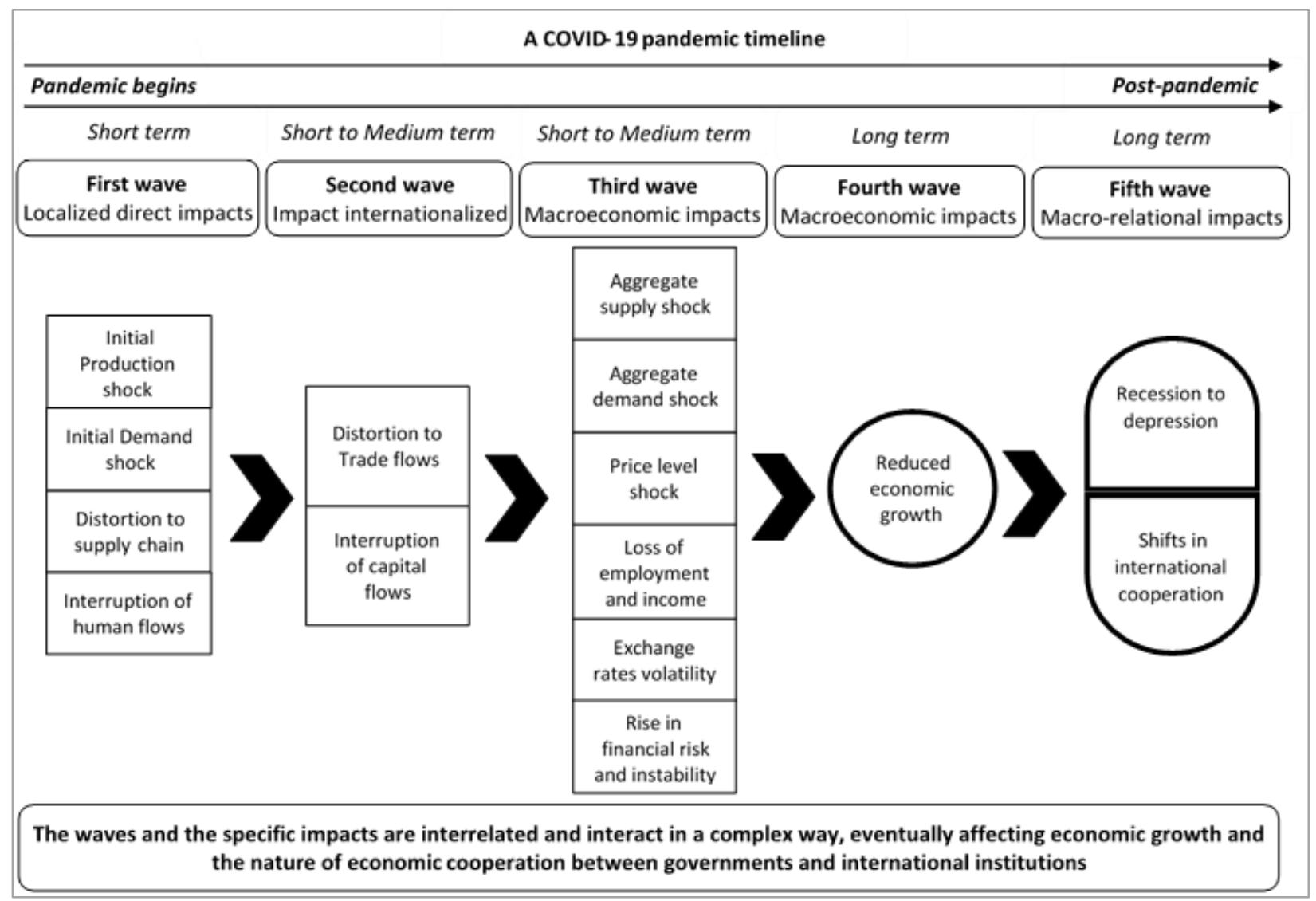

Source: Author developed

A concurrent shock to the country's production, demand, supply chain, and human flows is likely to result in a significant reduction in international trade flows of goods and services (the second wave); for example, a reduced supply, transport routes closures, lower demand for imported goods, and lesser movement of people from one country to the other - all could significantly reduce exports and imports of both goods (e.g., manufactured products such as automobiles) and services (e.g., tourism, travelling) for the economy. Furthermore, lesser people movement, economic uncertainty, and interrupted transports and logistics - coupled with higher costs of available options due to interruptions - could in combination force international investors to hold back on their on-going investment activities and plans in the pandemic-affected country. In general, this could hit resourcescarce developing economies the hardest that rely heavily on trade and foreign direct investments inflows for economic growth and development.

The effect on specific macroeconomic indexes could take some time to feel or to reflect in the numbers. A continued distortions in production, supply chain, demand, and 
flows of human, trade, and investment combined for a slightly longer period will begin damaging the macroeconomic indicators of the affected economy. The first of the hits should be a sizable reduction in aggregate supply and demand in the economy. The production shock discussed earlier explains the reduction in aggregate supply. With respect to aggregate demand, while demand for essential goods may increase (e.g., people may hoard food and medicine to face the uncertainty, more medicines are needed as more people become sick due to the outbreak), that of non-essential goods will reduce sharply (as people tend to save for the emergency, suspend non-essential consumption, and spend only for the need of the hour). This should lead to a net fall in the aggregate demand of the economy.

A reduced supply of goods and services will tend to push the price level up for essential goods and for those that are normally imported (since other affected economies may also experience same production and trade effects, reducing global supply); however, that is likely to be offset by the fall in price level of non-essential good, resulting in a deflationary pressure in the end. This is because of the differences in the demand elasticity of essential and non-essential goods. While increased demand and prices for essential goods could encourage some domestic producers to switch from non-essentials, they may not be able to take the full advantage if factories and business are sent to forced closure and/or their existing technology is not suitable for the switch.

Firms, under these circumstances, would be forced to lay-off a large number of workers in an effort to survive and remain financially feasible, which could significantly increase unemployment in the economy. This is likely as firms will face slump in business volume and revenues and increases in costs, which may push many firms not being able to service their wage payments and debts. Wage payment could be a bigger problem particularly for small businesses, who generally have lower financial cushion to fight downturns and thus are able to sustain as long as they are able to run profitably. Debt servicing could be particularly dreadful for firms whose debt-equity ratio is already higher. Many firms in such cases may default in repaying their debts for one or over a series of pay intervals, or in a more extreme case, may end up filing for bankruptcy and shutting down businesses permanently. The overall outcome of these effects is an increase in unemployment rate and decrease in income of people in the affected economy.

What happens to the overall macroeconomic performance in the end when key macro factors receive injuries? This could be understood by looking at economic growth commonly measured by the rate of Gross Domestic Product (GDP) growth of an economy. Once a pandemic-rippled economy faces widespread and adverse macro effects, GDP growth of the economy will slow down, as will be reflected over some quarters or a year (the fourth wave effect specified in the mapping). Such effect could be a 'decline in growth' in case of a 
normally growing economy or 'de-growth' in case of an economy currently facing stagnation. If such growth slowdown continues for a number of quarters or a year, the economy enters into recession (a condition when real GDP declines for two consecutive quarters (Callen, 2008) or decline in economic activities such as real GDP, real income, employment, industrial production, and wholesale-retail sales lasting for few months (Claessens \& Kose, 2009). In the fifth wave of impacts, the economy facing a continued de-growth or growth slowdown may find itself dip into recession, possibly falling to economic depression. Recovery from such pandemic-driven recession may be difficult and may continue for an even longer period, particularly because there is a lack of experience among policymakers, institutions, and researchers on how to fight a pandemic-driven recession. Since the recession or depression is not due to some known causes like a financial crisis, governments and multilateral organizations must come up with innovative and coordinated policies, with acknowledgement that traditional fiscal and monetary policies may prove ineffective (e.g., many economies already experience the zero lower bound problem).

During the recession or after it is over, there may be a significant change in how an economy deals with other economies at the international level. In the context of the pandemic, the shift may be influenced by the extent and nature of at list three factors: first, cooperation received on medication and outbreak management by the affected country from foreign countries; second, effects endured by both the affected country and their trading partners in the time of border lockdowns and trade restrictions; and third, financial and humanitarian aids and assistances received by the affected country from foreign countries. The affected country may evaluate the roles of their old friends, partners, and other economies in their hard times and may renew their foreign policy accordingly that will influence the country's post-pandemic international economic cooperation and relations.

All considered, while some of the effects presented in Figure 2 could occur concurrently, others could follow a 'wave-after-wave' process. While the impact mapping will be more relevant to economies having a greater influence in the world economy (such as China and G7 countries), it can still be utilized with regard to any affected country to systematically understand the macroeconomic effects produced by COVID-19. That said, the pandemic will generate significant economic cost burden on the affected countries, possibly larger for poor or developing countries since they have poor economic and health infrastructure; for example, direct cost incurred for the outbreak management during the pandemic (e.g., treatment and medications) and restoring the public health system in the post-pandemic period; such cost may be too high to afford for poor or developing countries (Vera, 2020, March 30). Furthermore, the COVID-19 pandemic is likely to generate loss of 
growth momentum for many economies and thereby forcing millions to fall into poverty, if no effective and timely action is undertaken.

\subsection{The observed effects of the COVID-19 outbreak so far}

From the moment the first case reported in December 2019, the global economy is perhaps experiencing the short-term and/or short to medium term effects. New reports are emerging almost every day depicting the economic consequences experienced by different economies. Being the initial epicenter of the outbreak, China has seen the short term or immediate effects before and more than anyone else; while for other economies, the effects are becoming visible slowly. Being the world's hub for global manufacturing and trade, immediate adverse effects on Chinese economy are making the economic cost burden rapidly globalized. For a systematic understanding, the effects emerged so far in research, reports, and media outlets, with regard to China and other economies, can be broadly framed using the general mapping shown in Figure 2. Data and information on economic effects across the waves with regard to many economies are readily unavailable. Given the origination, duration, and the scale of the pandemic as of today, there are relatively more published data and information on China than any other economy. Therefore, a brief discussion on the observed effects relating to the mapping follows, primarily with regard to China, although references are made to other economies where possible and suitable.

\subsection{Production, supply chain, demand, and human movement shocks:}

There are evidence emerging that the COVID-19 outbreak is creating an unprecedented havoc in the global supply chain, which primarily rely on Chinese manufacturing output and raw materials (Sheffi, 2020). There are two key channels of the global supply chain effects- one, production shocks and the other, shocks to trade flows due to transports and logistics disruptions. Chinese factories are affected by not only lockdowns and quarantines but also slowdown in production sites in other countries due to shortage of inputs from China, for example, raw materials, manufactured inputs, and machineries and equipment (Fernandes, 2020). Thus, a global supply chain shock beginning with production shocks primarily in China rapidly spills over other economies.

The scale of a production shock worldwide is large, as China occupies $60 \%$ of world supply and demand (GDP), $65 \%$ of world manufacturing, and $41 \%$ of world manufacturing exports (Baldwin \& di Mauro, 2020). Wuhan, the origin city of COVID-19, is ranked as $13^{\text {th }}$ out of 2000 Chinese cities by Bloomberg for its role in international supply chains (Daurat, 2020) and the $9^{\text {th }}$ best-performing city of China according to the Milken Institute ranking 
(Wong \& Lin, \& Jackson, 2020). With 3 national development zones, 4 scientific and technological development parks accommodating over 350 research institutes, 1656 hi-tech enterprises, and numerous enterprise incubators, the city received investments from 230 Fortune Global 500 firms (Bloomberg, 2020). Major export destinations for goods manufactured in Wuhan include the US, South Korea, Netherlands, India, Germany, Japan, U.K., Singapore, and Brazil (Kemp, 2020). This clearly indicates about the scale of ripple effects to be generated due to the lock-down of Wuhan alone for about two months. The production shock in China is driving a 'Bullwhip effect' in the global supply chain by forcing firms to reduce or shut down production and sales. For example, reports suggest that global fashion brand H\&M announced closure of 45 stores in China; other major brands including Gap, Uniqlo, Hugo, Ralph Lauren, Nike, Levi Strauss and Adidas also publicly announced about their store closures in central China (Biron \& Zhu, 2020). Not only apparels, large multinationals in the automobiles and transport industries such as Airbus, Damien Klassen, Toyota, General Motors, and Volkswagon also announced closing down their production facility in China (The Manufacturer, 2020; Leijen, 2020).

The other channel of global supply chain shock is disruptions in transports and logistics, which causes a halt in the movement of human and goods. Almost all major airlines including Lufthansa Group, Thai Lion Air, Spicejet, Lion Airlines across the world have completely or largely stopped international flights, as countries shut-down airports and restrict entry of international passengers (Pallini, 2020, March 26), and the number of international flights have reduced to 64,523 (Leigh, 2020). Airspace closure, travel bans, and the slump in the demand have forced 64 global airlines to stop their flying schedules (Pallini, 2020, March 26). Similarly, logistics company Freightos decided to layoff nearly 50 workers amidst the breakdown of their supply chain due to the pandemic concern and lockdown in China (Johnson, 2020). Air cargos like British Airways parent IAG are also in similar trouble (Robinson, 2020). German logistics group DHL, UPS and FedEx reported to face severe disruption in inbound and outbound logistics to and from China in air cargo shipments, trucking, and rail cargo services (Tirschwell, 2020). The unexpected supply chain breakdown have reportedly impacted industrial productions severely in not only China but also in many other economies, particularly in countries where producers have a backward or a forward linkage with the Chinese market; such impacts have spread across industries including automotive, pharmaceuticals, medical supplies, and high-tech manufacturing.

Another immediate effect of the pandemic is the restrictions imposed on movement of people across borders and within countries. The initial locked-down model of Wuhan is followed by China at the national level restricting inbound and outbound travelling of Chinese and foreign citizens. The lock-down measure is now being followed by almost all of 
the 200 countries and territories. One estimate suggests that about one third of the world's population so far are in locked-down condition (Hussain, 2020). The movement restrictions or bans have contributed to the immediate closure of businesses and factories forcing normal business operation to shut-down both within a country (e.g., China) and between countries.

Further to production, the pandemic is causing demand to squeeze as businesses close down and people lock themselves down at homes. However, demand response to the pandemic depends on the product type, e.g., essential or non-essential (including luxury). As people become worried about their health and lives, save money avoiding unnecessary shopping, and hoard essential commodities (e.g., food, medicines) during the lockdown, demand for essential goods is increasing; in contrast, demand for luxury or non-essential products shows a sharp fall. For example, global car sales shows a monthly decline of $10 \%$ in sales in January 2020; in China the reduction was by $20 \%$ in January (OECD, 2020) and by $92 \%$ during the first half of February (Jones \& Brown \& Palumbo, 2020, March 22). On the other hand, soaring demand for consumables in China has exceeded supply in retail stores (Petro, 2020, March 20; Zoe, 2020, March 21). Also, Chinese import demand of certain COVID19-related products from selected countries increased in Jan 2020 as compared to Jan 2019, particularly sterilizer imports almost tripled (ITC, 2020). Similar to China, shopping centers reported drop in footfall by up to 30\% in the US as of 18 March 2020 (Santos, 2020, March 23). In a similar fashion, an increasing number of reports show that demand for transportation, restaurant, travelling, tourism, and cinemas have declined sharply in the affected economies including China, as people maintain social distancing and lock down at homes; while staying home have caused increased demand for internet, television programs, and video games.

\section{$\underline{5.2}$ Effects on international trade and capital flows}

Reports available so far suggest that trade and capital flows are significantly slowing down due to the pandemic's effect. China's trading partners such as the US, the Europe, Japan, South Korea, Vietnam, India and Singapore face sharp decline in trade flows from and to China. Workman (2020, January 22) finds that China experiences a significant decline in shipments of almost all categories of goods including electrical equipment, machinery, furniture, lighting, plastic items, vehicles, knit, clothing, accessories, optical, technical, medical appliances and organic chemicals. Similarly, the US economy is concerned about heightened macroeconomic uncertainty, while facing a lower demand for US exports to China (Piven, 2020). In addition to the reduced trade flows now, the US government is concerned about problems that could be associated with importing Chinese goods and 
services in the next two years, as further complications (e.g., health, biosafety) may occur due to the virus. Similar to the US, economies across the world are facing significant disruptions in trading with China. For example, Wei \& Wang \& Verbraken (2020, February 17) suggests that New Zealand faces a large number of cancellations of their exports to China of different products including timber, seafood, and meat due to the pandemic.

There are a number of ways how global trade with China could be affected by the pandemic. A summary of the possible channels of effects and their possible timeline is reported in Table 1. China could face significant long-term trade barriers particularly from countries that are highly concerned about their domestic health quality and bio-safety (e.g., Australia). This means new forms of stringent trade barriers are likely to emerge, which may further aggravate trade between China and the rest of the world. For example, many economies might impose specific and enhanced health-related and bio-safety requirements (i.e., sanitary and phytosanitary barriers) for goods coming from China. All considered, China is set to face trade shocks originating from three sources - production declines and shut-downs, border lock-downs, and reductions in imports by other economies due to concerns over health and bio-safety of goods produced in China. The shocks are likely to hit Chinese exports the hardest relative to their imports, particularly in the long-run.

Further to merchandise trade, services trade, for example, in international tourism, travel, education globally, have almost come to a halt due to the pandemic, mainly because human-to-human contact is the main route of COVID-19 infection. This happens as economies impose restrictions and border lock-downs through air, road, and railway transportation routes. Since the outbreak, global tourist arrival has fallen dramatically. In China alone, the downfall has been as much as 10.9\% (Moore, 2020). WTO (2020) estimates that international tourist arrival could go down by 20-30\% in comparison to the 2019 figures, the effect of which is enormous. Reports estimate that the surge in flight cancellation may cause global airlines revenue to fall by US $\$ 4-5$ billion in the first quarter of 2020 (ICAO, 2020). Countries that are largely reliant on Chinese tourists are taking the big hit due to travel restrictions and border lock-downs in both China and the destination countries. For example, Australia's tourism faces a big shock, as about $15-16 \%$ of visitors in Australia are from China and they spend much more than tourists from the US, the UK, Japan, and New Zealand tourists put together (Farrer, 2020, February 7). Other countries such as Thailand, Italy, France, and Viet Nam may also face a similar situation. For example, reports suggest that the drop of Chinese travelers could cost Japan to lose around US $\$ 1.29$ billion of tourism revenue in the first quarter of 2020 while Thailand could lose $\$ 1.15$ billion (ICAO, 2020). A similar impact is evident in cargo transportation as well, as container ship operators receive cancellation of more than half of the previously ordered shipments to China (Paris, 2020). 
Table 1: Possible channels and timeline of COVID-19 effects on trade flows between China and the rest of the world

\title{
Channels
}

\section{Likely timeline of persistence}

\author{
Short-term Long-term
}

Bans or more stringent sanitary, phytosanitary, and technical barriers to Chinese exports to major markets such as Australia.

Reduced entry/allowance and stringent bio-safety and health compliance requirement of Chinese flag carrier ships, planes, and vehicles by countries to air, sea, and land ports.

Reduced entry/allowance of Chinese travelers to foreign countries and of foreign travelers to China

Reduced in-person cross-border business deals between Chinese and partner country private sector and governments.

Shift of production to alternative locations by MNEs currently operating in China; MNEs may consider safer and nearby location in efforts to reduce massive supply chain disruptions.

Shift of sourcing locations from China to other countries by large global importers of manufactured products.

Higher cost of transport and logistics services due to reduced trading routes for Chinese exports and imports.

Suspension of production and operation of foreign or MNEs in China; this might also reduce market opportunity for these companies in China.
Immediate, mostly temporary compliance may be imposed

Immediate, mostly temporary compliance may be imposed

Immediate, temporary measures due to border lock-downs and health concerns

Immediate, temporary measures due to border lock-downs and health concerns

Not likely to see in a great number in the short-run

Some temporary shift may happen due to travel bans and health concerns

Temporary rise in cost of trade

Immediate, temporary measures to avoid disease spread
Some measures may be long-term for over twothree years until safety is guaranteed

Some measures may be long-term for over twothree years until safety is guaranteed

Not likely to persist in the long-run, once crisis is over

Some measures may be long-term for over twothree years until safety is guaranteed

More permanent shifts could occur in the longrun if crisis persists

Some shifts could be long-term or permanent

Higher cost not likely to remain in longer period, once things get normal

Some closures may be long-term causing permanent business/factory shutdown, if crisis persists

Source: author developed 
Many countries having international higher education as a key contributor to their economy are set to see big shocks, as they impose harsher restrictions or bans on international arrivals. The US, the UK, and Australia may find zero arrivals of international students during the pandemic and significantly less in months after the pandemic recovery. Among other categories of services trade that are likely to be affected could include decline in in-person management consulting and international employment services in China-backed projects in different countries and foreign country or institution backed projects in China.

Further to international trade flows, capital flows are likely to experience a significant decline. As a result of the pandemic, investors are likely to take strategy to hold back, watch, and decide later on their investment plans. Also, in many countries, shutdowns prevent businesses to carry normal business operations including progressing on their investment plans. In many economies, corporations are rather focusing on fighting the immediate crisis of disease outbreak, putting back all their normal economic activities including investment. According to UNCTAD (2020), there are significant uncertainty about the future about the end to the pandemic and its economic consequences, which will hit private sector investment plans, particularly foreign direct investments. OECD (2020) estimates that higher uncertainty modelled through a rise of only 10 basis points in investment risk premia in all countries in the first half of 2020 increases the cost of capital and reduces investment significantly. Further to increased cost of capital, the other investment effect could arise due to delays in capital expenditure by multinational companies. Lower profit in foreign affiliates could lead to lower reinvestment earnings, a key component of FDI. UNCTAD (2020) reports that the world's top 5000 multinational enterprises (MNEs) have already revised their earnings estimates due to the COVID-19 effects, with a $9 \%$ average decline in earnings globally; the biggest hit on earnings is likely in Asia (-18\%), followed by transition economies (-16\%), while in the decline is about $16 \%$ in developing economies and 6\% in developed economies. According to UNCTAD (2020), out of the top 100 MNE's, 69 issued alerts regarding expected profit (41), production (12), sales (10), and both production and sales (19). Due to increased uncertainty and earnings slowdown, the downward investment pressure on FDIs particularly could range from $-5 \%$ to $-15 \%$ from previous marginal growth projections for 2020-2021 (UNCTAD, 2020).

Apart from the private sector, investment flows into projects under government to government cooperation between China and other economies are heavily hit by the COVID19 outbreak, at least temporarily. China backed private and public investment projects have been practically halted - as money, material, and project staff cannot flow between China and the partner nations. There is a possibility that while China tries to salvage from the 
pandemic, there could be delays or reductions in the size of future financial aid, loans, and investment flows to the partners economies compared to what China originally committed.

\section{$\underline{5.3 \text { Macroeconomic effects }}$}

As depicted in Figure 2, evidence with respect to several indicators can be examined to understand how and to what extent macroeconomic effects looks like.

\subsubsection{Aggregate supply shock}

The COVID-19 pandemic is set to cause a severe aggregate supply slump globally, driven by production shocks across economies including China (Fornaro \& Wolf, 2020), and evidence are already emerging in support of this. Latest data and reports show a substantial decline in industrial and services output across major economies who have experienced a quick spread of the pandemic. For example, China's official Purchasing Managers' Index (PMI) fell to a record low of 35.7 in February from 50.0 in January, according to the country's National Bureau of Statistics, which is well below the 50-point threshold and indicates a significant level of contraction in factory and production activities caused by the COVID-19 outbreak (CNBC, 2020, February 28). Other different PMIs of China also show similar signs; for example, the Caixin manufacturing PMI sank to 40.3 in February is down from January's 51.1 and the lowest reading since the survey began in 2004. Similarly, the official non-manufacturing (i.e., services) PMI measuring the services sector skidded to 29.6 in February from 54.1 in January (He, 2020, March 2). Other reports suggest that China's industrial production has fallen by about $13.5 \%$ in the first two months of 2020 (Jones \& Brown \& Palumbo, 2020, March 22). Figure 3 reports the PMI's of major economies including China.

Although official estimates are not public yet, Italy is likely progressing to a similar shock. Being the new epicenter of the outbreak, the country has locked down northern Italy which is the country's industrial powerhouse. Lombardy - an industrial region in northern Italy accounts for about $40 \%$ of Italian industrial output - is now locked down (Walker, 2020, March 1). Likewise, Britain's economic activities have been shrinking faster than the global financial crisis, which is reflected in the decline of the monthly PMI points at a quarterly rate of 1.5-2.0\% measured in the middle of March 2020 (Milliken, 2020, March 24). Milliken' (2020, March 24) show that the flash composite PMI sank to 37.1 in March from February's 53.0, the lowest since the measure started in January 1998, while the services component alone dropped to 35.7 from 53.2. Morgan Stanley forecasts a massive reduction in British economic output by around $10 \%$ or more in the three months ending 
in June, and just over 5\% for 2020 as a whole, with the optimism that social restrictions can be relaxed in the second half of the year (Milliken, 2020, March 24).

Figure 3: Changes in Purchasing Managers' Index of major affected economies

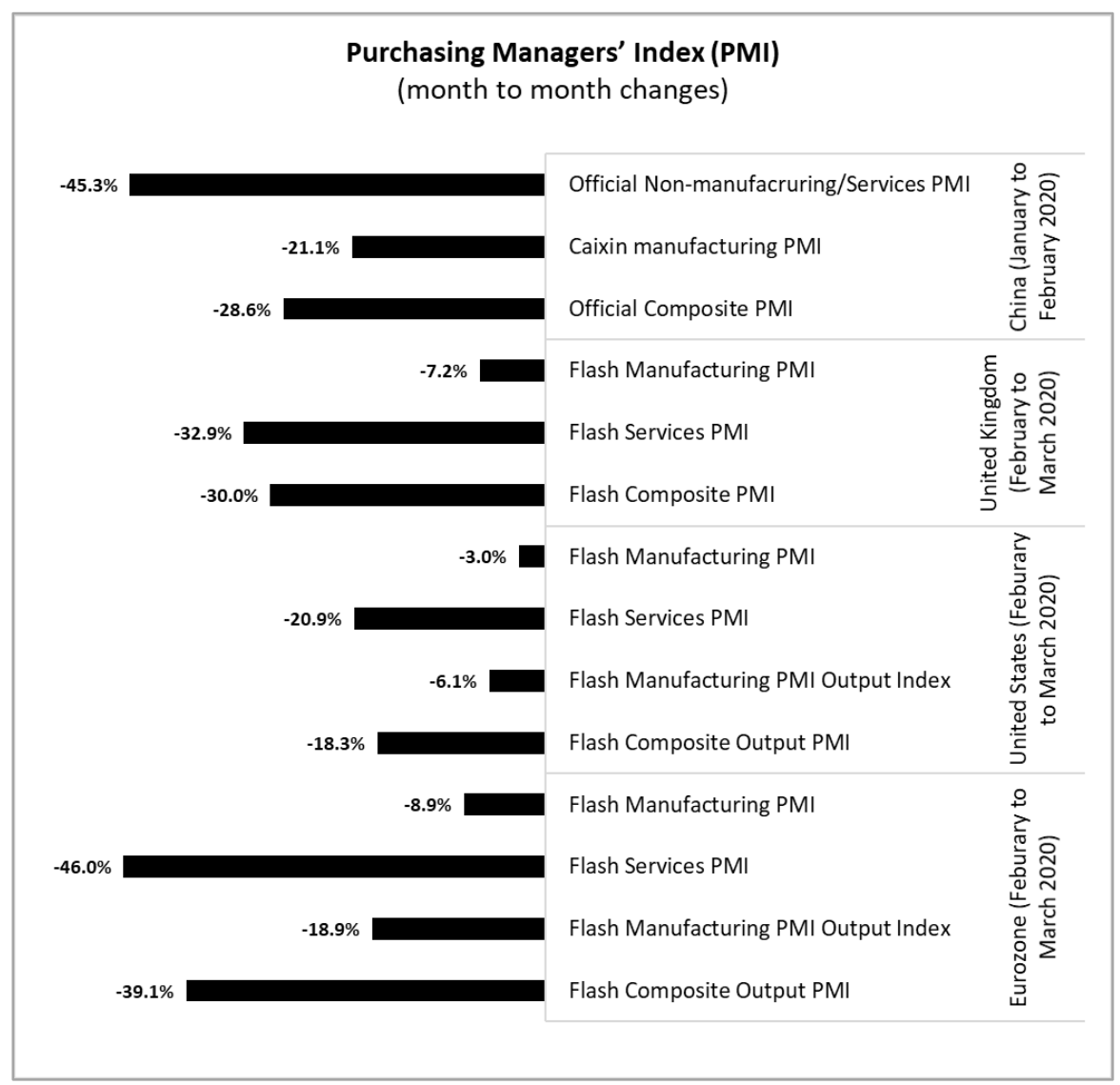

Source: Author compiled from He (2020, March 2); CNBC (2020, February 28); Milliken (2020, March 24); IHS Markit-CIPS (2020a,b,c,d)

Analysts and economists globally warn of a downturn in output for the rest of the current year for all the affected economies worldwide leading to a global slump in manufacturing and services output, which is to be severely worse if recovery from the pandemic is not made by the end of the year. Figure 3, shows the latest available PMIs of major economies compiled from different sources. The figure clearly shows that economic activities throughout major economies faces a great slump. Being an epicenter of the pandemic, business in the whole of Europe is collapsing like China. In March 2020, the flash Eurozone PMI declines to 31.4 from 51.6 in February, which is record low since July 1998 and the manufacturing PMI stands at 39.5 compared to 48.7 in February (lowest in 131month); similarly, the flash Services PMI is 28.4 falling to half of 52.6 in February (a record low since July 1998), while Manufacturing PMI stood at 44.8 from 49.2 in February - a 92- 
month low. Similar negative dive of all PMI indexes are observed for the US economy also, which could worsen in the next few months as the US becomes the current epicenter of the COVID-19 pandemic.

\subsubsection{Aggregate demand shock}

An increasing amount of evidence the aggregate demand shocks economies are enduring due to the COVID-19 outbreak. The pandemic is set to significantly decrease aggregate demand across economies and reduce global demand for goods and services (Fornaro \& Wolf, 2020). Aggregate demand in China and Hong Kong combined is reduced by $4 \%$ in the first quarter and $2 \%$ in the second quarter of 2020 , reflecting sharp declines in both investment spending and private consumptions (OECD, 2020). This is primarily driven by non-essential demand fall, such as automobiles and non-essential shopping (Jones et al., 2020, March 22; Santos, 2020, March 23). Retail shopping of essential goods and consumables has increased, resulting in empty retail shelves and emergence of 'daigou' shoppers across the world including China (Greg, 2020, March 20; Zoe, 2020, March 21). Aggregate demand in China and across economies is further affected by reduced demand for transportation, restaurant, travelling and tourism, and cinemas as people maintain social distancing and lock down at homes, while increased demand for internet, television programs, and video games as people stay home.

Demand is also declining in the international market. While Chinese import demand for medical supplies increased, overall import demand of China decreased by $2.9 \%$ from January 2019 to January 2020 (ITC, 2020). The International Energy Agency (IEA, 2020) suggests that as China is the world's largest oil importer in the world, global oil demand is likely to fall by 435 kilo barrels per day $(\mathrm{kb} / \mathrm{d}$ ) year-on-year in the first quarter of 2020 (the first quarterly contraction in more than 10 years) and demand growth in 2020 could fall by $30.7 \%$ to $825 \mathrm{~kb} / \mathrm{d}$ (the lowest since 2011) - all due to the Covid-19 and shutdown of China's economy. However, Chinese demand for essential goods in the international market have gone up significantly; the International Trade Center data shows that Chinese imports of

certain COVID19-related products from selected countries increased in Jan 2020 as compared to Jan 2019, particularly sterilizer imports almost tripled (ITC, 2020).

The net aggregate demand response in China or any affected economy depends on which response is relatively larger; if the reductions in aggregate demand for non-essential commodities and services offset the increases in aggregate demand for essential goods and services, overall aggregate demand of an economy is likely to decrease, and vice versa. While there is a tendency of increased supply in response to the increased demand for necessary 
goods, it is likely to fall far short to meet the whole of the excess demand in the short-run for two reasons - one, producers may not have excess capacity, and/or two, even if they have, they may not increase production significantly as doing this may increase some fixed cost that may not remain feasible once the excess demand is over.

\subsubsection{Shock to price level}

The reduced supply and demand for products produce direct consequences to the price levels in both national and international markets. Price level changes however are likely to depend on the type of goods. In the short-run, such as during or just immediately after the pandemic, an excess demand for essential goods relative to their supply in an economy is likely to push up the prices of those goods, while a reduced demand for nonessential goods relative to their supply is likely to reduce their prices. But since demand for non-essentials fall greatly relative to that for essentials, price changes of the former are likely to offset that of the latter. This could eventually lead to fall in the overall price level in an affected economy. In the long-run, prices of all goods and services could return to normal once the pandemic is over, if enough time is allowed to restore the market. Recent reports suggest evidence in support to this hypothesis. Chinese producer prices fell by $0.4 \%$ into deflation territory in February year-on-year, as a result of sluggish demand and prolonged manufacturing shutdowns that have left factories idle for months, according to the National Bureau of Statistics of China.

Table 2: Effects of COVID-19 on commodity prices in the international market

\begin{tabular}{lrcc}
\hline \hline \multicolumn{3}{c}{ Commodity Market Index/ Price } \\
\hline & 1512 & 1625 & $7.47 \%$ \\
Gold & 17.865 & 14.356 & $-19.64 \%$ \\
Silver Price & 65.6 & 21.83 & $-66.72 \%$ \\
Crude Oil (Brent) & 2.7925 & 2.172 & $-22.22 \%$ \\
Copper & 2.119 & 1.640 & $-22.61 \%$ \\
Natural Gas & & & 27-Mar-20 \\
\hline
\end{tabular}

Source: IG Portal (https://www.ig.com/en/)

On the other hand, the consumer-price index climbed by $5.2 \%$ in February from a year earlier and 5.4\% in January 2020, as slower growth in non-food prices outweighed the impact from mounting food inflation (Market Watch, 2020, March, 10). Food prices in China surged 21.9\% February from a year earlier, outpacing January's $20.6 \%$ gain and hitting the highest level since April 2008 (Market Watch, 2020, March, 10). Thus, China's 
inflation slowed because of larger decline in demand for non-food products relative to that for food (Bloomberg, 2020, March 10). Similar reactions are evident in other economies also. In the US, in the first week of March 2020, gasoline price fell sharply by $2.01 \%$ to US $\$ 2.38$ /gallon compared to the week before (Crudele, 2020, March 9).

Not only at the national level, prices are declining sharply at the international level due to the demand-supply shock and trade interruptions. Global equity prices and non-food commodity prices fell by $10 \%$ already (OECD, 2020). Gold, Crude Oil, Silver, Natural Gas, and Copper prices show higher volatility due to the Covid-19 epidemic, with a significant slump in the last three months, as shown in Table 2. Crude oil prices have experienced the harshest decline among the commodities in Table 2 through January to March period, as reflected in both WTF and Brent Crude Oil Index. Brent crude oil price sharply dropped by $66.7 \%$ in the last week of March from its US\$65.6 January price, the lowest level since 2001 (Jones, Brown \& Palumbo, 2020). Over the same period, similar declining patterns were observed for other major commodities in the international market; for example, prices fell for Silver spot price (XAG) by $19.6 \%$, Copper by $22.2 \%$, and Natural gas by $22.6 \%$. The only upside is that NASDAQ PHLX Gold/Silver Sector Index (XAU) index saw a slight improvement of Gold prices in the fourth week of March (Table 2), indicating that investors might be shifting towards safer investment opportunities.

\subsubsection{Effects on employment and income}

The aggregate demand and supply shocks are likely to result in a slump in employment opportunities; while new employment may not be created, there could more layoffs due to production cuts and business shutdowns across economies. The International Labor Organization estimates that global unemployment could rise between 5.3 million (low-case scenario) and 24.7 million (high-case scenario) based on global GDP growth estimates, while the mid-case estimate suggests an increase of about 13 million in unemployment. The estimates seem pertinent when compared to the unemployment rise by about 22 million due to the 2008-09 global financial crisis. In the United States alone, jobless claims at the end of March 2020 jumped to 3.28 million quadrupling prior record due to COVID-19 (Pickert, 2020, March 26). On the other hand, the quarantine and social distancing measures used for preventing COVID-19 spread directly shrinks economic activity and declines in labor supply. Estimates as of March 10 suggests that infected workers have generated a loss of nearly 30,000 work months, and a global loss of labor income could range between US\$860 and US\$3,440 billion. This could push millions of workers close to or below poverty line and leave economically and socially devastated in the post-pandemic period. According to the ILO (2020) estimates, an additional 8.8 million 
people (low-case scenario) fall into poverty around the world, while the number could be 20.1 million and 35 million in the mid and high case scenarios, respectively. Loss of jobs will be extremely painful for particularly poor and developing countries who heavily rely on export-oriented industries. For example, millions of low-wage workers in Bangladesh - the second largest apparel exporter in the world - are on the way to poverty, as factories receive cancellations of about $\$ 2.8$ billion orders from large western buyers and about $70 \%$ of the workers in the industry have already been sent home without a pay in the face a nationwide lockdown to fight the COVID-19 pandemic (Paton, E., 2020, March 31).

Past experience of epidemic and economic crises suggest that certain sections of the populations are affected disproportionately, which could potentially trigger worsening income inequality (Lee \& Cho, 2016). Since, unprotected workers - such as 'gig' or casual workers - do not have access to paid leave and social protection, the lockdown impact could damage their income stream disproportionately. Also, COVID-19 could threaten jobs of millions of migrant workers in the US, the Europe, the Middle East, and other developed countries, who normally work under stringent employment restrictions and conditions.

Figure 4: Average earnings revisions of top 5000 MNEs by major economies

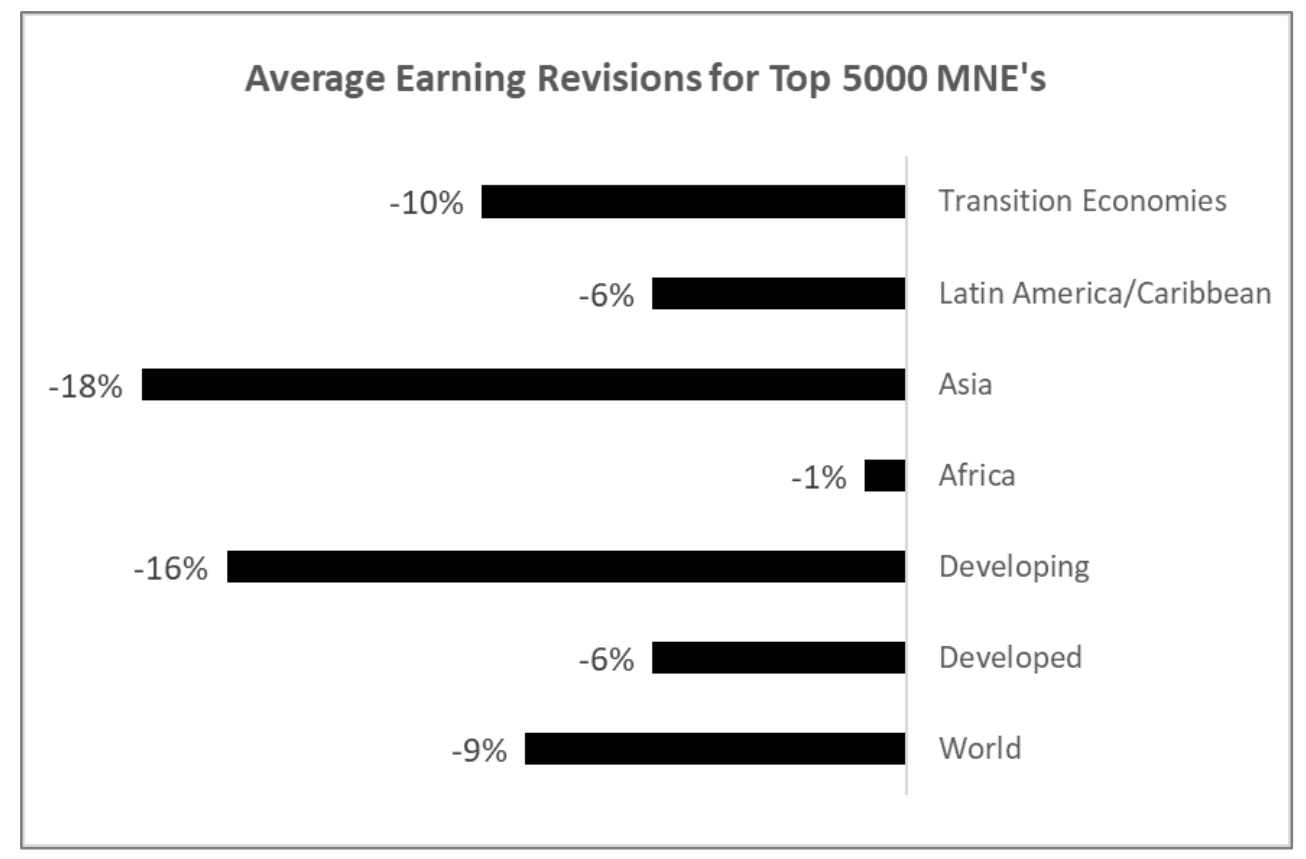

Source: UNCTAD (2020) 
The increases in unemployment is to be further aggravated by wage effects as corporate earnings are likely to shrink. UNCTAD (2020) suggests that the world's top 5000 multinational enterprises (MNEs) have recently revised their earnings estimates, showing a decline of $9 \%$ average decline in earnings globally due to the COVID-19 effects (Figure 4). Earnings are likely to take the biggest hit in Asia (-18\%) followed by transition economies $(-16 \%)$; MNEs are expecting a decline in earnings by about $16 \%$ in developing economies, while about 6 in developed economies. According to UNCTAD (2020), out of the top 100 MNE's, 69 have already warned about the impact of Covid-19 in the form of lower profit (41), sales (10), production (12), and both production and sales (19).

The earning shock would eventually end up with job and pay cuts, producing widespread decline in unemployment and wage income. Reports suggest that Chinese private companies have significantly cut wages, delayed salaries, and stopped paying employees altogether (Chen \& Hong, 2020). Many organizations - both businesses and nonbusiness organizations - are likely to introduce pay-cuts and/or delay in wage payment to both local and foreign employees due to not making enough money to cover the payroll. The layoffs in affected sectors could cause income loss and demand suppression and worsen the economic crisis - a condition known as 'negative multiplier effect' (El-Erian, 2020). School closures have resulted their employees losing about 30-50\% of their wages, and closed theme parks have asked workers to use up their paid vacation period and prepare for unpaid leave (Bloomberg, 2020).

In a recent survey of more than 9500 workers by a Chinese recruitment agency, one third expressed concerns about the possibility of losing wages, while new hiring has completely been stopped (Chen \& Hong, 2020). The impacts could be huge for developing countries who are major exporters of migrant labor and rely on their foreign remittances earned. Loss of jobs and delayed or non-payment of wages in different countries might significantly reduce remittance inflows to developing nations such as India and Bangladesh, putting extra pressure on their reserve and currency markets. In a continued crisis environment, temporary or permanent loss of jobs may force many to go back to their own nations and face economic misfortune and poverty. This would further aggravate unemployment situation in developing countries that are already experiencing economic and health shocks due to the COVID-19. The World Bank predict that such financial impact of coronavirus will restrain about 24 million people from escaping poverty in East Asia and the Pacific alone (Vaswani, 2020, 31 March). The remittance effect however could be confirmed once latest data are available. 


\subsubsection{Effects on exchange rates}

Foreign exchange market shows reactions to the panic-driven environment in the international and local markets. Major currencies such as GBP, Yuan, Euro, and Yen all weakened on against US Dollar from January to March 2020, with the major hit taken place in the second and third week of March (Table 3). Depreciations could be driven by the decline in trade flows and fewer international transactions, as the pandemic goes worldwide.

Table 3: Exchange rates of major currencies against one US Dollar

\begin{tabular}{lll}
\hline \hline Currency & 1-Jan & 26-Mar \\
\hline GBP & 0.76 & 0.84 \\
Yuan & 6.97 & 7.09 \\
Euro & 0.89 & 0.92 \\
Yen & 108 & 111 \\
\hline
\end{tabular}

Source: IG Terminal (https://www.ig.com/en/)

\subsubsection{Effects on financial stability and risk}

Financial systems are likely to be vulnerable to shocks to both the domestic and the international economic system (Beck, 2020; Cecchetti \& Schoenholtzon, 2020; and Cochrane, 2020). Financial markets globally responded negatively; major bourses for example S\&P 500, DowJones, Russell 2000, Nasdaq Composite, the FTSE 100, and the Nikkei 225 fell about 30-40\% by the end of March from their January values (The New York Times, 2020). The fall of indexes is unprecedented since the 1929 great depression (DeCambre, 2020). Alongside, credit spread has already widened and emerging market assets are experiencing reallocation.

Financial institutions are at great risk due to COVID-19 effects. For example, banks globally could face increased credit and default risk, as business generate cash insufficient to service debt due to business closures, shut-downs, and lower demand for goods and services during both the pandemic and post-pandemic periods. Furthermore, there could be lower business prospects for lending institutions, as private sector investment and consumption keeps declining or do not improve both during the pandemic and after it is over. Many lending or investment decisions being postponed for now may not see light again, while cost of financing for financial institutions particularly for banks may increase due saving erosion or lower availability of money in the hands of people while facing the pandemic. While Federal Reserve has already reduced the policy rate to increase liquidity to tackle the impacts, the measure has created increased concern for the health of financial 
institutions, particularly of banks (Adrian, 2020). Further to banks, insurance companies are also likely to face cash drains as a coupled effect of a greater number of claims and lower premium collections due to people's inability to pay. In addition, the pandemic could force insurers to think and redesign their life and health insurance products accommodating such pandemic possibilities. Furthermore, investment banks may face significant business downturn as underwriting business may dip and investment opportunities may not yield adequate returns.

\section{$\underline{5.4 \text { Economic growth effects and the looming recession }}$}

Economists and relevant agencies globally estimate reduced global economic growth due to the on-going pandemic, as the end to it remains completely uncertain. The IMF head forecasts that the epidemic could damage global economic growth this year, followed by a rapid economic rebound (Bangkok Post, 2020). While Oxford economics warns that the global spread of the virus could cost about $\$ 1.1$ trillion in lost income and $1.3 \%$ of global GDP outside the Asia region (Inman, 2020), some estimates suggest that global economic growth could reduce by $0.2-0.3 \%$ (Klebnikov, 2020). Fernandes (2020) estimates GDP growth could decline by $3-5 \%$ in a mild scenario depending on the country, with a cost of about $2-2.5 \%$ of global GDP growth for each additional month of shutdown. While serviceoriented economies will take the larger hits, countries such as like Greece, Portugal, and Spain (that are largely reliant on tourism) will be more affected by this crisis. Meanwhile, the outbreak is already having a significant impact on Asian markets, industries, and global growth (JP Morgan, February 20, 2020). Forecast suggest that the China's economic growth this year is likely come down to 3.5-4\% in the first quarter (Mishra, 2020); the worsened scenario in 2020 is painful as the pandemic adds to the injury the Chinese economy endures from the US-China trade war.

Recently revised growth estimates by OECD (2020) suggest a significant growth decline for the world economy compared to their earlier estimates in November 2019 (Figure 5). Assuming that the epidemic peaks in China in the first quarter of 2020 and outbreaks in other countries prove mild and contained, global growth could be lowered by around 0.5\% this year compared to estimates reported in the November 2019 economic outlook (OECD, 2020). Accordingly, annual global GDP growth is projected to drop to $2.4 \%$ in 2020 as a whole, from an already weak $2.9 \%$ in 2019 , with growth possibly negative in the first quarter of 2020 (OECD, 2020). Prospects for China have been revised markedly by OECD (2020), with growth slipping below 5\% this year, as adverse impacts on confidence, financial markets, the travel sector and disruption to supply chains contributes to the 
downward revisions in all G20 economies in 2020, particularly the ones strongly connected to China (such as Japan, Korea and Australia). A longer lasting and more intensive coronavirus outbreak, spreading widely throughout the Asia Pacific region, Europe and North America, could cause global growth drop to $1.5 \%$ per cent in 2020, half the rate projected prior to the outbreak.

Figure 5: OECD Real GDP growth projections, March, 2020 vs November 2019

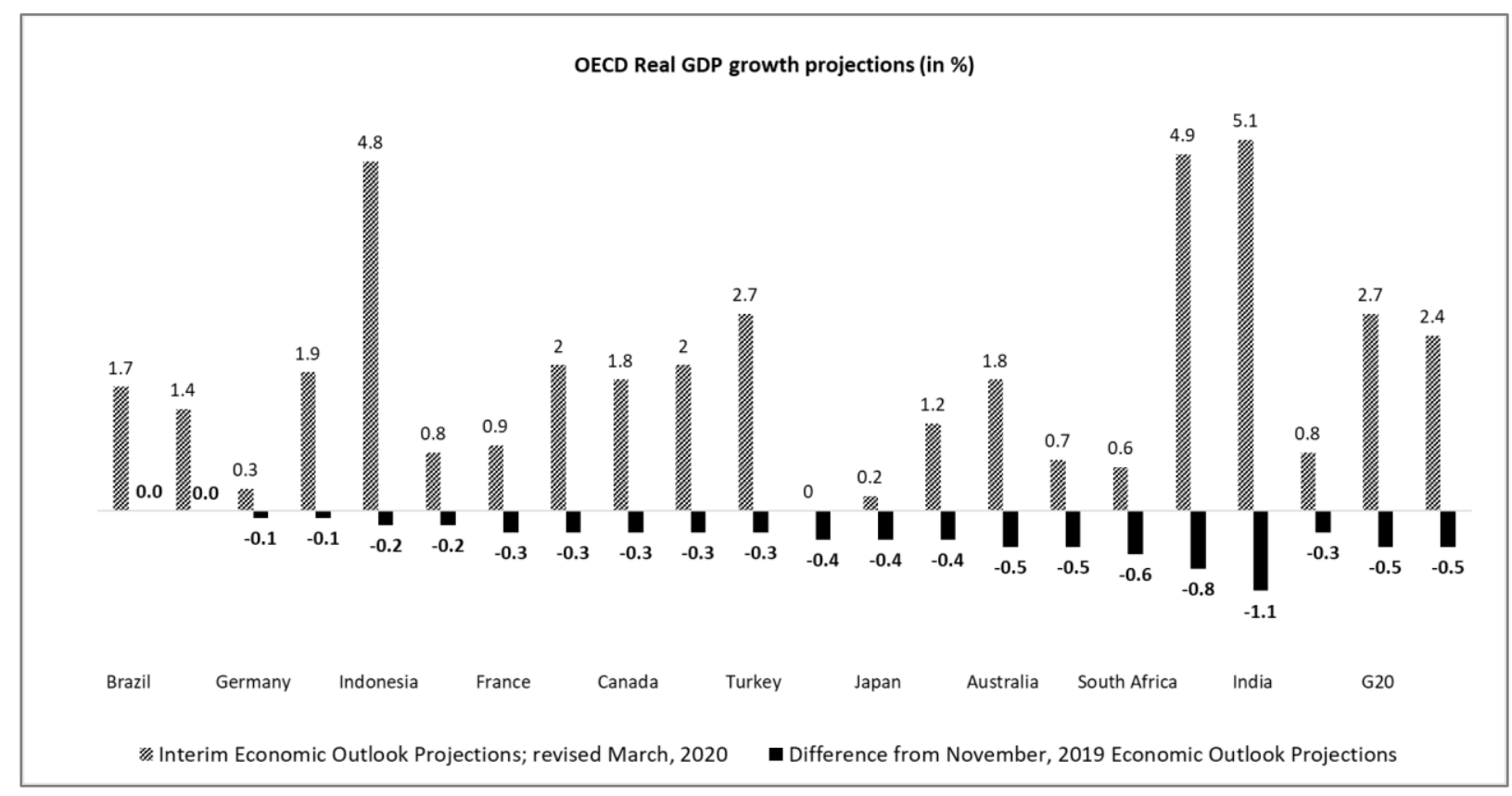

Source: Interim Economic Outlook, OECD (2020)

Considering available estimates, economists, markets, and relevant agencies (e.g., the International Monetary Fund, the OECD) warn of a looming economic recession. While the recession has not started yet, economists fear of a depression across economies worse than financial or economic rises the world has seen ever before (Islam, 2020, March 20; DW, 2020, 27 March; OECD, 2020). However, many believe that the process of delivering a recession globally has already started, although the course remains unrecognizable (Carlsson-Szlezak, Reeves, and Paul Swartz, 2020, March 27; El-Erian, 2020, March 17; Schwartz, 2020, March 21). Although uncertain and difficult to predict yet, the shape of the COVID-19 driven recession is likely to be different for different economies (such as V, U, or L shaped) (Carlsson-Szlezak \& Reeves, \& Paul Swartz, 2020, March 27; Tooze, 2020, March 18; Hutt, 2020, February 17). 


\subsection{Potential for shifts in international relations and economic cooperation}

The COVID-19 so far is showing symptoms of renewal and revision of international relationship and economic cooperation. There could be some positive outcomes in the area of relationships between nations, as countries extend help to each other and try to fight the pandemic through friendly collaboration. The unprecedented systemic challenges thrown by the COVID-19 pandemic, and the global responses seen already, could foster the transformation of the traditional patterns of donor-recipient aid relations towards a new model of international cooperation between all countries (Prizzon, 2020, March 26). However, even during the pandemic, the relationship between China and the US remains volatile; while war of words and accusations about the origin of the virus remains open, discussions of joint efforts also happen between the two nations to fight the pandemic (Fuchs, 2020).

The pandemic could have international relationship effects in at least two ways: first, affecting the existing and the upcoming economic programs under government to government (G2G) cooperation particularly between China and other economies, and second, renewed partnership and friendship driven by assistance and aid (mainly medical related) exchanges between governments. The first one mainly relates to the increasing Chinese investments globally. Due to the outbreaks, China backed public projects under investment or aid frameworks have come to halt - as materials and project staff cannot travel back and forth (Fazl-e-Haider, 2020), which could even cause delays or cancellation of G2G aid or investment programs as China and their partner countries concentrate on recovery from the pandemic. Currently, China has about 7000 projects underway in 69 countries under G2G cooperation framework, which could have a big hit due to this pandemic. The economic cooperation effects may also extend to another highly ambitious plan of China - the Belt and Road Initiative (BRI) which connects 69 countries around the world through road and seaway trade routes (Coppel \& Liu, 2018). It is important to note that although COVID-19 spread many economies outside China, the country first extended their major medical assistance with doctors and medical supplies to Italy before anyone else in the Europe. Even other European or EU nations. The extended assistance could be attributed to two important marks - first, China came to help Italy in their dire times when no other nations in the European Union or the greater Europe remained silent (Wood, 2020); and second, Italy is the first European nation endorsing and approving the BRI initiative (Giuffrida, 2020), indicating that economic interests may have played a role in deciding who to share with China's experience, expertise, and resources in the hours of need. However, following Italy, China has extended similar support in small or large scale to many 
other economies globally. While these friendly gestures definitely have a humanitarian and solidarity aspects of helping in the times of need, they could play a significant role in developing or renewing international relationships in the post-pandemic world between China and the rest of the world. Yet, these implications to international relationships and economic cooperation remain possibilities and can only be validated over time.

\subsection{A simple illustration of growth effect and recession with standard macroeconomic model}

The COVID-19 effect on GDP is likely to through a complex interaction of several factors discussed so far; and therefore, explaining the effects with standard macroeconomic models could be difficult and incomplete (Baldwin \& di Mauro, 2020). Accepting this limitation, a simple macroeconomic model of Aggregate Demand (AD) and Aggregate Supply (AS) is used below to represent the likely effect of the COVID-19 outbreak on GDP in an economy. The illustration however is subject to some assumptions - first, the economy operates in full employment normally and produces the equilibrium level of GDP determined by the long-run $\mathrm{AS}$ and the $\mathrm{AD}$; second, all macroeconomic effects of the COVID-19 outbreak (e.g., the macro effects discussed so far) are eventually reflected through the AD and AS of the economy; and third, aggregate demand and supply in an economy are combinations of demand for and supply of essential goods (e.g., food, medicine) and nonessential goods (e.g., cars, tourism) - the two broad categories this paper highlights throughout. The illustration helps to understand the available evidence on the demand and supply shocks discussed in the earlier sections.

\section{Figure 6: COVID-19 effects on essential and non-essential goods markets and GDP}

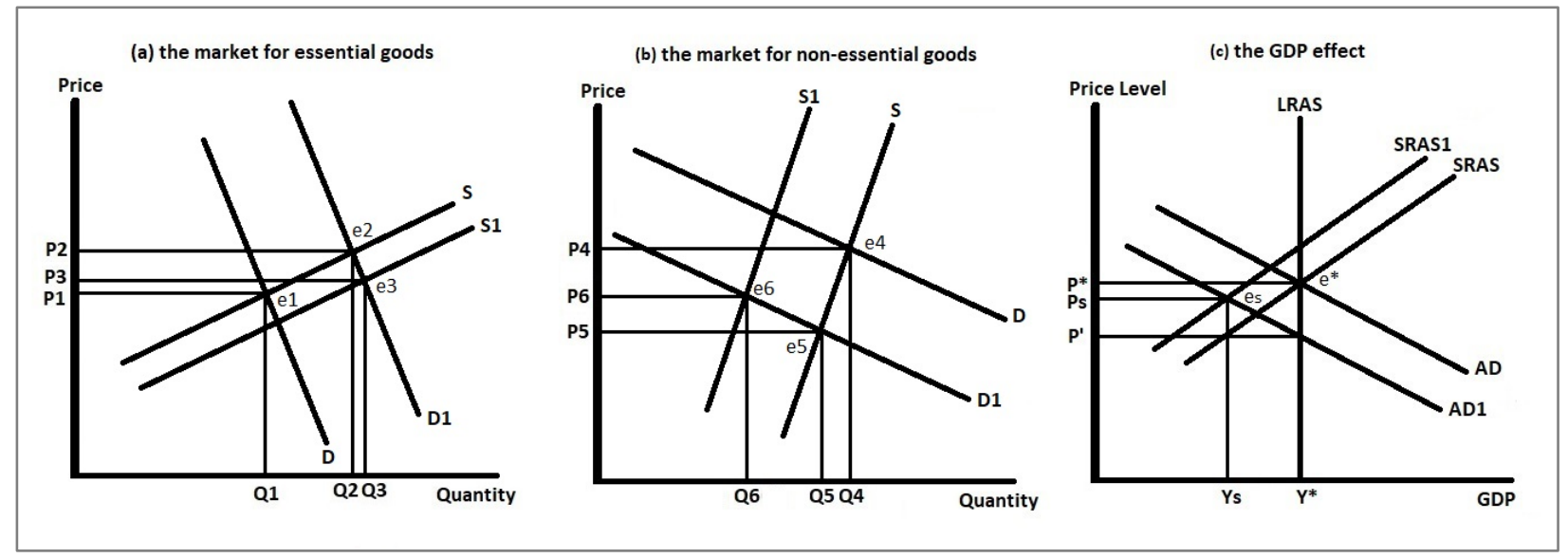

Source: Author developed 
Figure 6 shows three panels that reflect the likely effect of COVID-19 on essential goods market, non-essential goods market, and an economy's GDP. In panel (a), the market's initial equilibrium for essential goods is at e1 with quantity Q1 and price P1. During the pandemic, demand for essential goods such as food and medicine rises significantly as explained in the earlier sections of this paper. In panel (a), increases in demand for essential goods is reflected by a shift from the initial demand curve D to D1. As a result, prices for essential goods increases to P2 and an increased quantity of goods Q2 is traded. As demand for essential foods like medicine and medical supplies increase, many producers may begin switching to produce these goods from what they normally produce; for example, in the US, companies including General Motors have joined in producing Ventilators (DeBord, 2020), and in China, many companies stopped producing their regular goods and started producing masks and other supplies (Reagan, 2020). Furthermore, there could be greater imports of such goods in an affected economy. As a result, supply could increase slightly in response to the huge demand increases, shifting the supply curve from $\mathrm{S}$ to $\mathrm{S} 1$; the shift however is not likely to be too large for at least two reasons: one, producers shifting from other trade (e.g., automobile) may not have enough technology, skill, and experience to produce essential (e.g., medical) supplies at a bulk volume like a regular producer; and two, as the pandemic spreads worldwide, import demand for goods like medicine and medical supplies go up globally - which is what the world is experiencing now (e.g., import demand for medical supplies such as mask, ventilators, testing kits, and personal protective equipment, etc. increased in all countries across the world including Italy, UK, Spain, Japan, Korea, and USA). Furthermore, production of many essential goods such growing food in a short period of time may not be too easy. An increase in the level of supply now leads to new equilibrium of e3, where now more quantity of essential goods Q3 is traded at a price P3; the price is yet lower than P2 - the price attained due to huge shoot up in demand in the first instance. However, P3 is still higher than P1, suggesting that if no more producer enters into the market, prices of essential goods are likely to remain higher than what it was during the normal times (P1 here). The good part of course is that demand for these goods are now met at a level greater than the normal times. As discussed before in this paper, there are evidence emerging that demand for essential goods like food and medicine is increasing, pushing prices for these goods up in China and other countries.

Figure 6 panel (b) shows the market reaction to the changes in demand for and supply of non-essential commodities. Emerging evidence cited in the paper earlier show that there is a substantial decrease in demand for non-essential and luxury goods such as car. Pane (b) shows that the market for non-essential goods is at the initial equilibrium e4, 
where Q4 quantity is traded at a price of P4. As demand falls sharply and substantially, demand curve pushes back from D to D1, immediately causing prices to decline from $\mathrm{P} 4$ to P5 and quantity traded from Q4 to Q5. Due to temporary businesses and factory closures and permanent business shut-down and bankruptcy over a long-lasting pandemic period, many producers may be out of the market over time. This would push the production and supply of essential goods down from their initial level; such production cut could also be contributed by two other factors: one, many producers may divert resources to producing essential goods instead of their regular non-essential goods (e.g., General Motors in the US), and two, a slump in global demand for non-essential and luxury goods would result in a lower export demand. The supply cut is represented in panel (b) as the leftward shift of the market supply curve S to S1; this leads to a slight increase in price to $\mathrm{P} 6$ trading a lower Q6 quantity. However, the increased price P6 is still lower than the initial price level P4, primarily because the slump in demand prevents prices to go back to that level.

For an economy, aggregate demand effect depends on the total effect of demand for essential and non-essential goods and similar would happen for aggregate supply also, since the model assumes a broader classification of all goods produced in an economy into essential and non-essential categories. In the event of the COVID-19 pandemic, evidence cited in this paper suggest that the magnitude of demand reduction of non-essential goods offsets increases in demand for essential goods. Under the circumstances, combining the demand effects of both essential and non-essential goods, aggregate demand in the economy should go down from their normal level. On the other hand, the increases in supply of essential goods is likely to be fairly little, while decreases in supply of non-essential goods is likely to be relatively larger, causing aggregate supply to fall. This is because supply would tend to respond according to the magnitude of demand reductions for both goods. The supply response is justified given the fact that the share of non-essential industrial goods in total production is significantly larger than the share of essential goods in most economies.

Figure 6, panel (c) show an initial long-run AD-AS full-employment equilibrium of an economy at $\mathrm{e}^{*}$, where the economy produces $\mathrm{Y}^{*}$ level of GDP at $\mathrm{P}^{*}$ price level. In the short-run, a reduction of aggregate demand and aggregate supply due to the pandemic effects is reflected by the shift of the AD curve to AD1 and SRAS1. This causes the economy to arrive at point es, where the economy is likely to produce a lower GDP of 'Ys' compared to its full-employment level $\mathrm{Y}^{*}$ at a lower price level Ps from $\mathrm{P}^{*}$. This means, in the shortrun an economy is likely to face a lower national output and income coupled with a deflationary pressure, and which if continues would lead to recession. In the long-run, if the economy is able to restore its output but unable to increase aggregate demand, the economy 
achieves GDP of $\mathrm{Y}^{*}$ but price level would fall further to $\mathrm{P}^{\prime}$. This suggests that, restoring the macroeconomic equilibrium to the full-employment level or at least closer to that in the long-run should come with a significant and upward demand shock.

\subsection{The looming recession}

As depicted in Figure 6 panel (c), a continued deflation gap would force the economy to fall into a long-term economic recession, which would require a substantial demand shock to recover. One important lesson from Figure 6 for any economy is that it runs the risk of embracing recession as a result of the COVID-19 economic adversities, which may sustain for a longer duration if appropriate, effective, and timely fiscal or monetary measures are not undertaken to impose the required demand shock. The outcome of the standard macroeconomic analysis supports Fornaro and Wolf (2020) who, using a variant macroeconomic model, show that the spread of the virus might cause a demand-driven slump, give rise to a supply-demand doom loop, and then open the door to stagnation traps induced by pessimistic animal spirits. Fornaro and Wolf (2020), in line with this paper, suggest that the COVID-19 outbreak will cause a negative supply shock to the world economy, by forcing factories to shut down and disrupting global supply chains. While a recession is seemingly imminent due to COVID-19, its shape or 'shock geometry' however will depend on the shock's ability to damage an economy's supply side and capital formation. In a situation, where credit mobilization is disrupted, the capital stock doesn't grow, recovery remains slow, workers exit the workforce, skills are lost, and productivity is down, then the shock becomes structural (Carlsson-Szlezak \& Reeves, \& Swartz, 2020, March 27). In the most unfortunate case, countries may be trapped into economic depression.

\subsection{What's next?}

While the macro effect symptoms of COVID-19 are becoming increasingly visible in different economies, a growth effect hasn't reflected yet at least in a visible or measurable way. But as researchers and economists agree about a looming recession and possibly a depression across economies, the world has no time to spare in the preparation to face it. Realizing this, governments in many affected countries, particularly the large ones, have already announced monetary and fiscal policy measures. Countries such as the US, the UK, China, Australia, Canada, and Malaysia have already reduced their benchmark interest rates in a desperate bid to boost up the economy, however, economists think it won't be enough (Letzing, 2020, March 18). For many countries, it is not feasible to reduce benchmark rates as their rates already reached close to zero in the normal times. Apart 
from these, countries have already taken or are considering several other way outs, for example, quantitative easing, direct market interventions, and fiscal stimulus and bailout packages. For example, the US has passed huge nearly US\$2 trillion stimulus package to revive the economy (Cornwell \& Morgan \& Shepardson, 2020, March 25).

Since the pandemic induces both aggregate supply and demand shocks, it is very difficult to address the impacts with standard macroeconomic tools (Baldwin and di Mauro, 2020). Economists and policy makers agree that governments need to take up a combination of well-targeted, extreme, and new kind of fiscal and monetary policy actions that the world perhaps has never seen before (Letzing, 2020, March 18; OECD, 2020; Baldwin \& di Mauro, 2020). In this context, Baldwin \& di Mauro (2020) highlight a range of targeted fiscal and monetary measures for firms, households, healthcare, public confidence, and finance and banking that can be implemented at the national level and through international collaboration (e.g., G7 level).

The biggest challenge in responding to address the pandemic is that the crisis is totally different, unprecedented, and king of new, and not like an economic crises driven by known causes such as banking crisis or financial crisis. As this time it is different, traditional approach may not work properly. Therefore, any policy measure to be undertaken as a response to this crisis needs to be designed considering the following key attributes:

- first, measures should be 'all-inclusive' or as comprehensive as it can be instead of targeting one particular agent, activity, or area of the economy;

- second, measures need to be innovation driven, since for many economies, traditional policies may not be as effective as it needs to be (e.g., covering pandemics under national health systems services coverage);

- third, to deal with a globalized pandemic like the COVID-19 that no country can fight alone, measures must be coordinated at the cross-border level, such as at the regional (e.g., Asia, Latin America), economic union (e.g., EU, African Economic Union), and trade block (e.g., BRICS, NAFTA), or other cooperation (e.g., G20, SAARC) levels;

- fourth, poor and most developing economies by default have a fragile economic environment with poor health infrastructure; to help them recover during the pandemic and the post-pandemic period, the supranational agencies such the World Bank need to introduce special economic and health programs and packages; and

- fifth, to assist poor and developing economies survive the crisis, developed countries and international institutions like the World Bank and the IMF may think of revising their terms of existing and future financing to reduce the economies' external debt burden. 


\subsection{Conclusion}

COVID-19 is jeopardizing economies - no matter large or small, developed or developing. As of today, end to this pandemic remains uncertain. The uncertainty is causing loss of public confidence worldwide. The macroeconomic impacts in any economy are likely to worsen across economies, if consumer and producer confidence is lost and a powerful demand shock coupled with massive supply-side supports cannot be implemented in a timely manner. In the current context, recovery from the disease is primary and economics is secondary. However, as evidence of economic adversities emerge, it would be wise to begin from now designing and implementing aggressive and innovative policy actions with a longterm perspective to prevent the looming. Or, if someone waits for the pandemic to end before taking effective measures, it might too late and an economic depression might become inevitable and unavoidable. 


\section{References}

Arezki, R. and Nguyen, H. (2020) Novel coronavirus hurts the Middle East and North Africa through many channels. In Baldwin, R. and di Mauro, B.W. (eds). Economics in the Time of COVID-19. A VoxEU.org Book, Centre for Economic Policy Research, London. Accessed 26 March 2020 at: https://voxeu.org/system/files/epublication/COVID-19.pdf

Baldwin, R. and di Mauro, B.W. (eds). (2020). Economics in the Time of COVID-19. A VoxEU.org Book, Centre for Economic Policy Research, London. Accessed 26 March 2020 at: https://voxeu.org/system/files/epublication/COVID-19.pdf

Beck, T. (2020). Finance in the times of coronavirus. In Baldwin, R. and di Mauro, B.W. (eds). Economics in the Time of COVID-19. A VoxEU.org Book, Centre for Economic Policy Research, London. Accessed 26 March 2020 at: https://voxeu.org/system/files/epublication/COVID-19.pdf

Biron, B., \& Zhu, Y. (2020). Major fast-food chains and retailers in China are shutting their doors as the deadly coronavirus continues to spread. Here's a list of closures. Business Insider. Accessed 31 March 2020, from https://www.businessinsider.com/coronavirus-fears-mcdonalds-starbucks-close2020-1

Bloomberg (2020, March 10). China's Inflation Slows as Coronavirus Locks Down Economy. Bloomberg News. Accessed March 21 at: https://www.bloomberg.com/news/articles/2020-03-10/chinese-inflation-slows-infebruary-factory-deflation-returns

Bloomberg. (2020). Wuhan Virus Lockdown Casts Cloud Over Industry \& Tech Hub. Bloomberg News. Accessed 31 March 2020, from https://www.bloomberg.com/news/articles/2020-01-24/wuhan-virus-lockdowncasts-economic-cloud-over-china-s-chicago

Boone, L. (2020). OECD Economic Outlook. Organisation for Economic Co-operation and Development. Accessed 25 March 2020 from https://www.oecd.org/economicoutlook/

Boone, L. (2020). Tackling the fallout from COVID-19. In Baldwin, R. and di Mauro, B.W. (eds). (2020). Economics in the Time of COVID-19. A VoxEU.org Book, Centre for Economic Policy Research, London. Accessed 26 March 2020 at: https://voxeu.org/system/files/epublication/COVID-19.pdf

BullionVault. (2020). Gold Price Chart, Live Spot Gold Rates, Gold Price Per Ounce/Gram — BullionVault. Accessed 26 March 2020, from https://www.bullionvault.com/gold-price-chart.do\# 
Callen, T. (2008). What Is Gross Domestic Product?. Finance \& Development, December, International Monetary Fund. Accessed 22 March 2020 at: https://www.imf.org/external/pubs/ft/fandd/2008/12/pdf/fd1208.pdf

Carlsson-Szlezak, P., Reeves, M., and Swartz, P. (2020, March 27). Understanding the Economic Shock of Coronavirus. Harvard Business Review. Accessed 29 March 2020 at: https://hbr.org/2020/03/understanding-the-economic-shock-of-coronavirus Cecchetti, S.G. and Schoenholtz, K.L. (2020). Contagion: Bank runs and COVID-19. In Baldwin, R. and di Mauro, B.W. (eds). Economics in the Time of COVID-19. A VoxEU.org Book, Centre for Economic Policy Research, London. Accessed 26 March 2020 at: https://voxeu.org/system/files/epublication/COVID-19.pdf

Chen, L., \& Hong, J. (2020). Coronavirus hits China's workers as businesses say they can't pay wages now. Fortune. Accessed 31 March 2020, from https://fortune.com/2020/02/19/coronavirus-china-workers-businesses-pay-wages/ Claessens, S. and Kose, M.A. (2009). What Is a Recession?. Finance \& Development, March, International Monetary Fund. Accessed 22 March 2020 at: https://www.imf.org/external/pubs/ft/fandd/2009/03/pdf/fd0309.pdf

CNBC (2020, February 28). China factory activity shrank at its fastest rate on record in February. CNBC. Accessed 22 February 2020 at: https://www.cnbc.com/2020/02/29/china-pmi-factory-activity-shrank-at-fastestrate-on-record-in-february.html

Cochran, J.H. (2020). Coronavirus monetary policy. In Baldwin, R. and di Mauro, B.W. (eds). Economics in the Time of COVID-19. A VoxEU.org Book, Centre for Economic Policy Research, London. Accessed 26 March 2020 at: https://voxeu.org/system/files/epublication/COVID-19.pdf

Cohen, J., \& Kupferschmidt, K. (2020). Strategies shift as coronavirus pandemic looms. Science, (6481), 962-963. Accessed from https://science.sciencemag.org/content/367/6481/962

Coppel, K., \& Liu, A. (2018). New Frontier: The 2018 Report. Knight Frank Research. Accessed from https://content.knightfrank.com/research/1438/documents/en/newfrontiers-the-2018-report-2018-5216.pdf

Cornwell, S., Morgan, D., and Shepardson, D. (2020, March 25). What's in the nearly $\$ 2$ trillion U.S. Senate coronavirus stimulus?. World Economic Forum. Accessed 27 March 2020 at: https://www.weforum.org/agenda/2020/03/senate-coronavirusstimulus-covid19-united-states-health-economics/

Crudele, J. (2020, March 9). Oil price drops and coronavirus lead to cratering stock market. New York Post. Accessed March 21 at: 
https://nypost.com/2020/03/09/oil-price-drops-and-coronavirus-lead-to-crateringstock-market/

Daurat, C. (2020). Tracking the Wuhan virus outbreak's impact on business and travel The Japan Times. Accessed 31 March 2020, from https://www.japantimes.co.jp/news/2020/01/27/business/wuhan-virus-impactbusiness-travel-china/\#.XoNnD062ODI

DeBord, M. (2020). General Motors and Ford are ramping up ventilator production to fight the coronavirus pandemic. Here's where they are now. Business Insider. Accessed 31 March 2020, from https://www.businessinsider.com/coronavirusgeneral-motors-ford-ventilator-production-progress-2020-3

DeCambre, M. (2020). The Dow is on pace for its worst month since the Great Depression, but here's why all hope isn't lost amid the coronavirus crisis. Market Watch. Accessed 31 March 2020, from https://www.marketwatch.com/story/thedow-is-on-pace-for-its-worst-month-since-the-great-depression-but-heres-why-allhope-isnt-lost-amid-the-coronavirus-stock-rout-2020-03-21

di Mauro, B.W. (2020). Macroeconomics of the flu. In Baldwin, R. and di Mauro, B.W. (eds). (2020). Economics in the Time of COVID-19. A VoxEU.org Book, Centre for Economic Policy Research, London. Accessed 26 March 2020 at: https://voxeu.org/system/files/epublication/COVID-19.pdf

DW (2020, March 27). Coronavirus and the economy: World 'clearly' in recession, IMF says. Deutsche Welle. Accessed 29 March 2020 at:

https://www.dw.com/en/coronavirus-and-the-economy-world-clearly-in-recessionimf-says/a-52943601

Eichengreen, B. (2020, March 12). Coronanomics 101: which policy tools will contain the economic threat of COVID-19?. World Economic Forum. Accessed 15 March 2020 at: https://www.weforum.org/agenda/2020/03/coronavirus-economics/

El-Erian, M.A. (2020, March 17). The Coming Coronavirus Recession and the Uncharted Territory Beyond. Foreign Affairs. Accessed 27 March 2020 at: https://www.foreignaffairs.com/articles/2020-03-17/coming-coronavirus-recession

Farrer, M. (2020, Februaru 7). Coronavirus economic impact: Australia could be among world's hardest hit nations. The Guardian. Accessed 22 March 2020 at: https://www.theguardian.com/world/2020/feb/08/coronavirus-economic-impactaustralia-could-be-among-worlds-hardest-hit-nations

Fazl-e-Haider, S. (2020). Coronavirus brings a halt to China's trillion-dollar Belt and Road Initiative. The New Arab. Accessed 31 March 2020, from 
https://english.alaraby.co.uk/english/indepth/2020/3/11/chinas-belt-and-roadinitiative-affected-by-coronavirus

Fernandes, N. (2020). Economic Effects of Coronavirus Outbreak (COVID-19) on the World Economy. March 22. Available at SSRN:

https://ssrn.com/abstract=3557504 or http://dx.doi.org/10.2139/ssrn.3557504

Fornaro, L. and Wolf, M. (2020). Covid-19 Coronavirus and Macroeconomic Policy. Working Paper, Centre de Recerca en Economia Internacional (CREi). Accesed 27 March 2020 at: http://www.crei.cat/wp-content/uploads/2020/03/C19-1.pdf

Fuchs, M. (2020). The US-China coronavirus blame game is undermining diplomacy. The Guardian.Accessed 31 March 2020, from https://www.theguardian.com/commentisfree/2020/mar/31/us-china-coronavirusdiplomacy

Giuffrida, A. (2020). Italy and China in plan for new Silk Road-style trade network . The Guardian. Accessed 31 March 2020, from https://www.theguardian.com/world/2019/mar/23/italy-china-new-silk-road-beltand-road-g7

He, L. (2020, March 2). China's factories just had a historically terrible month because of the coronavirus, CNN Business. Accessed 24 March 2020 at: https://edition.cnn.com/2020/03/01/economy/china-pmi-economycoronavirus/index.html

Hussain, S. (2020). One third of humanity under virus lockdown. AFP.Accessed 31 March 2020, from https://www.afp.com/en/news/15/one-third-humanity-under-viruslockdown-doc-1q57be13

Hutt, R. (2020, February 17). The economic effects of COVID-19 around the world. World Economic Forum. Accessed 22 March 2020 at: https://www.weforum.org/agenda/2020/02/coronavirus-economic-effects-globaleconomy-trade-travel/

IEA (International Energy Agency) (2020). Oil Market Report. International Energy Agency, 13 February 2020. Accessed 26 February 2020 at:

https://webstore.iea.org/download/direct/2968

IHS Markit (2020a). Caixin China General Services PMI, 4 March 2020. News Release, Caixin and IHS Markit. Accessed 29 March 2020 at: https://www.markiteconomics.com/Public/Home/PressRelease/53021485aa334b7e9 2c1662643b6a974

IHS Markit (2020b). Caixin China Manufacturing PMI, 2 March 2020. News Release, Caixin and IHS Markit. Accessed 29 March 2020 at: 
https://www.markiteconomics.com/Public/Home/PressRelease/7826fe514cf84a7ab2 $83 \mathrm{~b} 9 \mathrm{~d} 585 \mathrm{c} 412 \mathrm{e} 6$

IHS Markit (2020c). IHS Markit Flash Eurozone PMI, 24 March 2020. News Release, IHS Markit. Accessed 29 March 2020 at:

https://www.markiteconomics.com/Public/Home/PressRelease/30078c37216c413bb 410af22ae547068

IHS Markit (2020d). IHS Markit Flash U.S. Composite PMI, 24 March 2020. News

Release, IHS Markit. Accessed 29 March 2020 at:

https://www.markiteconomics.com/Public/Home/PressRelease/7bf04abd12954a858 $1 \mathrm{c} 25 \mathrm{bc} 4 \mathrm{~d} 9 \mathrm{f} 5 \mathrm{e} 93 \mathrm{a}$

IHS Markit (2020e). IHS Markit/CIPS Flash UK Composite PMI, 24 March 2020. News

Release, Chartered Institute of Procurement \& Supply (CIPS) and IHS Markit.

Accessed 29 March 2020 at:

https://www.markiteconomics.com/Public/Home/PressRelease/0f164ac0128b429ea 1c329104afd62c3

ILO (International Labor Organization). (2020). COVID-19 and the world of work:

Impact and policy responses. International Labour Organization (ILO) Note - 18

March 2020. Accessed 22 March 2020 at:

https://www.ilo.org/wcmsp5/groups/public/---dgreports/---

dcomm/documents/briefingnote/wcms 738753.pdf

International Labour Organization. (2020). COVID-19 and the world of work: Impact and policy responses. Genève. Accessed from https://www.ilo.org/wcmsp5/groups/public/---dgreports/--dcomm/documents/briefingnote/wcms 738753.pdf

ITC (2020). Trade Map Data. International Trade Centre. Available at: https://www.trademap.org/.

Johnson, E. (2020). Logistics Technology: Covid-19 forces Freightos into proactive layoffs. JOC.Accessed 31 March 2020, from https://www.joc.com/technology/freightprocurement-systems/covid-19-forces-freightos-proactive-layoffs 20200317.html

Jones, L., Brown, D., \& Palumbo D. (2020, March 28). Coronavirus: A visual guide to the economic impact. BBC News. Accessed 29 March 2020 at https://www.bbc.com/news/business-51706225

Kemp, S. (2020). China City \& Industry Report: A Guide for U.S. Exporters. Bejing: US Commercial Service. Accessed from https://2016.export.gov/china/build/groups/public/@eg*cn/documents/webcontent Leg'cn'105813.pdf 
Lee, A., \& Cho, J. (2016). The impact of epidemics on labor market: identifying victims of the Middle East Respiratory Syndrome in the Korean labor market. International journal for equity in health, 15(1), 196.

Leigh, G. (2020). The Number Of Daily Flights Is Now Dropping Drastically: The Latest In Aviation. Forbes. Accessed 31 March 2020, from https://www.forbes.com/sites/gabrielleigh/2020/03/30/the-number-of-daily-flightsis-now-dropping-drastically-the-latest-in-aviation/\#701c2b9943d4

Leijen, M. (2020). European car factories closed over concerns coronavirus. Railfreight. Accessed 31 March 2020, from https://www.railfreight.com/business/2020/03/18/european-car-factories-closedover-concerns-coronavirus/?gdpr=accept

Letzing, J. (2020, March 18). How many policy tools are left to soften the impact of COVID-19?. World Economic Forum. Accessed 27 March 2020 at: https://www.weforum.org/agenda/2020/03/covid-19-coronavirus-policy-toolseconomic-impact/

Mann, C.L. (2020). Real and financial lenses to assess the economic consequences of COVID-19. In Baldwin, R. and di Mauro, B.W. (eds). Economics in the Time of COVID-19. A VoxEU.org Book, Centre for Economic Policy Research, London. Accessed 26 March 2020 at: https://voxeu.org/system/files/epublication/COVID19.pdf

MarketWatch (2020, March 10). Coronavirus sends food prices soaring in China. MarketWatch. Accessed 22 March 2020 at: https://www.marketwatch.com/story/coronavirus-sends-food-prices-soaring-inchina-2020-03-10

McKibbin, W and Fernando, R. (2020). The economic impact of COVID-19. In Baldwin, R. and di Mauro, B.W. (eds). (2020). Economics in the Time of COVID-19. A VoxEU.org Book, Centre for Economic Policy Research, London. Accessed 26 March 2020 at: https://voxeu.org/system/files/epublication/COVID-19.pdf

Meninno, R. and Wolff, G. (2020). As coronavirus spreads, can the EU afford to close its borders?. In Baldwin, R. and di Mauro, B.W. (eds). Economics in the Time of COVID-19. A VoxEU.org Book, Centre for Economic Policy Research, London. Accessed 26 March 2020 at: https://voxeu.org/system/files/epublication/COVID19.pdf

Milliken, D. (2020, March 24). Coronavirus hits UK economy with unprecedented force. Reuters. Accessed 26 Match 2020 at: https://www.reuters.com/article/us-britain- 
economy-pmi/coronavirus-hits-uk-economy-with-unprecedented-forceidUSKBN21B14A

Moore, M. (2020). APAC: COVID-19 impact on tourist arrivals by country or region 2020 - Statista. Accessed 1 April 2020, from https://www.statista.com/statistics/1103147/apac-covid-19-impact-on-touristarrivals-by-country/

OECD (2020). Coronavirus: The world economy at risk. OECD Interim Economic Assessment, 2 March. Organization for Economic Cooperation and Development. Accessed 18 March 2020 at: https://www.oecd.org/berlin/publikationen/InterimEconomic-Assessment-2-March-2020.pdf

Pallini, T. (2020, March 26). 55 global airlines have completely stopped flying scheduled flights due to travel bans, airspace closures, and low demand for travel - see the full list. Business Insider. Accessed 31 March 2020 at:

https://www.businessinsider.com/coronavirus-global-airlines-stopping-flightssuspending-operations-2020-3\#tame-45

Paris, C. (2020). Coronavirus Rattles Shipping Industry as Supply Shock Moves to Demand Decline. Wall Street Journal. Accessed 1 April 2020, from https://www.wsj.com/articles/coronavirus-rattles-shipping-industry-assupply-shock-moves-to-demand-decline-11585249552

Paton, E. (2020, March 31). 'Our Situation is Apocalyptic': Bangladesh Garment Workers Face Ruin. New York Times. Accessed 31 March, 2020 at: https://www.nytimes.com/2020/03/31/fashion/coronavirus-bangladesh.html

Petro, G. (2020, March 20). The Coronavirus Tsunami: What's To Come For U.S. Retail. Forbes. Accessed 26 March 2020 at:

https://www.forbes.com/sites/gregpetro/2020/03/20/the-coronavirus-tsunamiwhats-to-come-for-us-retail/\#128e4da6609d

Pickert, R. (2020, March 26). U.S. Jobless Claims Jump to 3.28 Million, Quadruple Prior Record. Bloomberg. Accessed 28 March 2020 at: https://www.bloomberg.com/news/articles/2020-03-26/u-s-jobless-claims-surged-torecord-3-28-million-last-week?

Prizzon, A. (2020, March 26). How coronavirus is accelerating a new approach to international cooperation. Overseas Development Institute. Accessed 28 March 2020 at: https://www.odi.org/blogs/16794-how-coronavirus-accelerating-newapproach-international-cooperation 
Reagan, C. (2020). Retailers shift production to make masks, gowns for health-care workers in coronavirus pandemic. $C N B C$. Accessed 31 March 2020, from https://www.cnbc.com/2020/03/26/coronavirus-retailers-make-masksgowns-forhealthcare-workers.html

Robinson, M. (2020). BA grounds ALL flights to and from Gatwick due to coronavirus. MailOnline. Accessed 31 March 2020, from https://www.dailymail.co.uk/news/article-8170635/BA-grounds-flights-Gatwickcoronavirus.html

Sandbu, M. (2020). Coronavirus: the moment for helicopter money. Financial Times .Accessed 27 March 2020, from https://www.ft.com/content/abd6bbd0-6a9f-11ea800d-da70cff6e 4 d 3

Santos, D. (2020, March 23). How Shopping Centres Globally are Responding to Coronavirus (Updated Frequently). Aislelabs. Accessed 26 March 2020 at: https://www.aislelabs.com/blog/2020/03/23/how-shopping-centres-respondingcoronavirus/

Schwartz, N.D. (2020, March 21). Coronavirus Recession Looms, Its Course ‘Unrecognizable'. The New York Times. Accessed 27 March 2020 at: https://www.nytimes.com/2020/03/21/business/economy/coronavirusrecession.html

The Manufacturer. (2020). The best and worst case for UK supply chains affected by the coronavirus. The Manufacturer. Accessed 31 March 2020, from https://www.themanufacturer.com/articles/best-worst-case-uk-supply-chainsaffected-coronavirus/

The New York Times. (2020). Travel Limits, Economic Fears Stoke Market Plunge.New York Times. Accessed 31 March 2020, from https://www.nytimes.com/2020/03/12/business/stock-market-today.html

Tirschwell, P. (2020). COVID-19: Coronavirus creating unprecedented container shipping disruption. JOC. Accessed 31 March 2020, from https://www.joc.com/maritimenews/container-lines/coronavirus-creating-unprecedented-container-shippingdisruption`20200221.html

Tooze, A. (2020, March 18). Is the Coronavirus Crash Worse Than the 2008 Financial Crisis?. Foreign Policy. Accessed 27 March 2020 at: https://foreignpolicy.com/2020/03/18/coronavirus-economic-crash-2008-financialcrisis-worse/ 
UNCTAD (2020). Impact of the Coronavirus Outbreak on Global FDI. Investment Trends Monitor, Special Issue - March 2020. United Nations Conference on Trade and Investment. Accessed 28 March 2020 at: https://unctad.org/en/PublicationsLibrary/diae gitm34 coronavirus 8 march2020.pd $\underline{\mathrm{f}}$

UNWTO. (2020). International Tourist Arrivals Could Fall by 20-30\% in 2020. Accessed 1 April 2020, from https://www.unwto.org/news/international-tourism-arrivalscould-fall-in-2020

Vaswani, K. (2020, March 31). Coronavirus: Millions will be left in poverty, World Bank warns. BBC Business. Accessed 31 March 2020 at: https://www.bbc.com/news/business-52103666

Vera, C. (2020, March 30). As coronavirus spreads to poorer countries, here's how the world can help. World Economic Forum. Accessed 31 March 2020 at: https://www.weforum.org/agenda/2020/03/coronavirus-developing-countriesinequality-debt-oxfam/

Voth, J. (2020). Trade and travel in the time of epidemics. In Baldwin, R. and di Mauro, B.W. (eds). Economics in the Time of COVID-19. A VoxEU.org Book, Centre for Economic Policy Research, London. Accessed 26 March 2020 at: https://voxeu.org/system/files/epublication/COVID-19.pdf

Walker. A. (2020, March 1). Coronavirus: Italian economy takes a body blow. BBC World Service. Accessed 24 Match 2020 at: https://www.bbc.com/news/business$\underline{51650974}$

Wei, Z., Wang, J., \& Verbraken, T. (2020, February 12). The coronavirus epidemic: Implications for markets. MSCI. Accessed 21 March 2020 at: https://www.msci.com/www/blog-posts/the-coronavirus-epidemic/01718848208

Whalen, J., \& Bhattarai, A. (2020). U.S. companies face crucial test over China's factory shutdown. Washington Post. Accessed 31 March 2020, from https://www.washingtonpost.com/business/2020/02/25/us-companies-so-far-aresurviving-chinas-factory-shutdown-next-few-weeks-are-crucial/

Wilson, A. (2020). Coronavirus travel updates: which countries have restrictions and FCO warnings in place? The Guardian. Accessed 31 March 2020, from https://www.theguardian.com/travel/2020/mar/24/coronavirus-travel-updateswhich-countries-have-restrictions-and-fco-warnings-in-place 
Wong, P., C.Y. Lin, M., \& Jackson, J. (2020). Best-Performing Cities China 2019. Milken Institute. Accessed from https://milkeninstitute.org/reports/best-performing-citieschina-2019

Wood, J. (2020). China is sending medical experts and supplies to help Italy fight coronavirus. World Economic Forum. Accessed 31 March 2020, from https://www.weforum.org/agenda/2020/03/coronavirus-covid-19-italy-chinasupplies/

Wood, Z. and Sweney, M. (2020, March 20). Coronavirus shutdown ravages high street as retailers take emergency action. The Guardian. Accessed 26 March 2020 at: https://www.theguardian.com/business/2020/mar/20/marks-and-spencerconsiders-temporary-store-closures-wetherspoons-coronavirus

Wren-Lewis, S. (2020). The economic effects of a pandemic. In Baldwin, R. and di Mauro, B.W. (eds). Economics in the Time of COVID-19. A VoxEU.org Book, Centre for Economic Policy Research, London. Accessed 26 March 2020 at: https://voxeu.org/system/files/epublication/COVID-19.pdf 